Universidade de Brasília - UnB

Instituto de Ciências Humanas - IH

Departamento de Serviço Social - SER

Mariana Macedo Queiroga

\title{
Implicações do Neoliberalismo na Política Social Brasileira: o modelo de proteção social do Governo Lula
}

Brasília, dezembro de 2006. 


\title{
Mariana Macedo Queiroga
}

\section{Implicações do Neoliberalismo na Política Social Brasileira: o modelo de proteção social do Governo Lula}

\author{
Trabalho de Conclusão de Curso de \\ graduação apresentado ao \\ Departamento de Serviço Social da \\ Universidade de Brasília, para a \\ obtenção do grau de assistente \\ social. \\ Orientadora: Prof a Dra Potyara \\ Amazoneida Pereira Pereira
}

Dezembro de 2006. 


\section{Resumo}

Este Trabalho de Conclusão de Curso (TCC) se insere como um dos produtos de pesquisa mais ampla realizada no Núcleo de Estudo e Pesquisa em Política Social (Neppos), do Centro de Estudos Avançados Multidisciplinares (CEAM), entre 2004 e 2006, período em que a autora participou como bolsista. Buscando conhecer as implicações do neoliberalismo na política social brasileira a partir das medidas adotadas pelo Governo Lula na efetivação dessa política até o ano de 2006, esta monografia se aprofundou no debate teórico do neoliberalismo, da política social e dos direitos sociais, na perspectiva do método histórico-estrutural, conjugando metodologias antigas, como a pesquisa qualitativa, a técnicas recentes, como a entrevista simulada. Dentro do modelo de proteção social do Governo Lula, foram analisados em profundidade dois programas federais: o Programa Bolsa Família e o Programa Nacional de Microcrédito Produtivo Orientado (PNMPO), que forneceram dados essenciais à análise realizada no último capítulo, que reconheceu algumas singularidades, desafios e limitações da proteção social de Lula.

Palavras-chaves: neoliberalismo; proteção social; Governo Lula. 


\section{Agradecimentos}

A Potyara Pereira, minha orientadora, pela paciência e incentivo; às examinadoras deste TCC: professoras Maria Auxiliadora César e

Cilene Lins; às queridas Liliane Fernandes, Narla Galeno e Daniela Barros, minhas colaboradoras no NEPPOS, por compartilharem achados de pesquisa e pela amizade; aos professores do Departamento de Serviço Social da UnB; à turma do primeiro semestre de 2003, em especial, aos amigos do coração Ricardo Soares, Gizélli Oliveira, Delma Borges e Márcia Viana; a Kelly Tavares e aos colegas de curso e de profissão, aos meus amigos e à minha família, pela força, e a Deus. 


\section{Sumário}

Introdução

Metodologia

1. Referencial Teórico 9

$\begin{array}{ll}\text { 1.1 Categorias Analíticas } & 18\end{array}$

a) Neoliberalismo 18

b) Política Social $\quad 20$

c) Direitos Sociais $\quad 24$

2. O neoliberalismo no contexto brasileiro 27

2.1 A singularidade do Governo Lula 30

3. A proteção social no Governo Lula 33

3.1 Programas sociais analisados 33

3.2 Análise dos programas sociais selecionados 35

3.3 Desafios e limitações 43

$\begin{array}{ll}\text { Conclusões } & 46\end{array}$

Referências Bibliográficas $\quad 48$ 


\section{INTRODUÇÃO}

Este trabalho constitui o produto final da disciplina "Trabalho de Conclusão de Curso" (TCC) cursada no Departamento de Serviço Social no segundo semestre de 2006. Tendo o objetivo de fomentar a pesquisa em Serviço Social, o referido TCC, além de uma exigência curricular, é um momento de síntese e expressão da totalidade da formação profissional e reflexo do amadurecimento acadêmico da aluna.

O presente trabalho estabelece ligação estreita com a pesquisa "Projetos Alternativos às Políticas Sociais Neoliberais", financiada pelo CNPq, coordenada pela professora Potyara Amazoneida Pereira Pereira e realizada no Núcleo de Estudo e Pesquisa em Política Social - NEPPOS, do Centro de Estudos Avançados Multidisciplinares - CEAM, da Universidade de Brasília, no qual a autora deste trabalho participa como Bolsista de Iniciação Científica. Constitui um desdobramento do Plano de Trabalho da bolsista intitulado "As implicações do neoliberalismo na estrutura econômico-social e na política social brasileira".

Ciente da influência do neoliberalismo sobre as políticas sociais brasileiras, desde os anos 1990, o estudo aqui realizado busca aprofundar o debate a respeito das implicações desse modelo sócio-econômico no contexto do Governo Lula. Dedica-se, particularmente, ao estudo das implicações do neoliberalismo sobre estas políticas por meio da análise das concepções e práticas de proteção social adotadas no país.

Constitui objeto desta pesquisa a concepção, a prática e as implicações sociais das políticas sociais públicas desenvolvidas no Brasil, no Governo Lula, tendo como termo de comparação o domínio da ofensiva neoliberal, nesse período. Não se trata aqui de estudar apenas a conquista de hegemonia pelo ideário neoliberal no país, mas a sua aplicação e influência direta no modelo de proteção adotado no período de 2002 até os dias atuais.

O objetivo geral deste trabalho foi o de conhecer as implicações do neoliberalismo na política social brasileira a partir das medidas adotadas pelo Governo Lula na efetivação dessas políticas até o ano 2006. Os objetivos específicos consistiram em verificar se a concepção de proteção social adotada pelas políticas sociais públicas, em especial as do Governo Lula, leva em conta as necessidades sociais dos pobres no Brasil; compreender em que medida o modelo de proteção social adotado pelo Estado permite o acesso dos brasileiros pobres aos direitos sociais; e avaliar as implicações da primazia do mercado sobre as garantias sociais na formulação das políticas públicas. 
Inicialmente, este trabalho apresenta e demarca as características do neoliberalismo e da política social neoliberal, para, em seguida, registrar a conduta neoliberal face às políticas sociais, direitos sociais e justiça. Finalmente, compara-se com os resultados da análise efetuada o que o Brasil vem realizando em termos de política social, especificamente no Governo Lula (2002-2006). Os programas preferencialmente analisados no presente trabalho serão o Bolsa-Família e o Microcrédito Produtivo Orientado.

Utilizando fontes secundárias para a investigação, que serão mais adensadas e especificadas abaixo, a hipótese aqui levantada é a de que as políticas sociais do Governo Lula, assim como as ações dos governos anteriores, adotaram o modelo de proteção social neoliberal baseado na primazia dos interesses do mercado sobre as necessidades da população brasileira, causando impactos danosos à eficiência das políticas sociais, do ponto de vista da satisfação dessas necessidades.

A investigação buscou alcançar os seguintes resultados: 1) Evidenciar os efeitos negativos das políticas sociais neoliberais na condição de vida da população; 2) Analisar o modelo de proteção social implementado pelo Governo Lula; 3) Desmistificar a idéia de que o Governo Lula, por ser vinculado a um partido de esquerda, tenha contrariado a lógica de intervenção dos dois governos anteriores, de direita, e com o ideário neoliberal. 


\section{METODOLOGIA}

A especificidade da pesquisa social delimita as características básicas que foram levadas em conta neste trabalho. A metodologia aqui utilizada considerou o objeto de estudo de acordo com pontos definidos por Minayo (2000): primeiro que o objeto das Ciências Sociais é histórico; segundo, que existe identidade entre sujeito e objeto da investigação; terceiro que toda ciência social é intrínseca e extrinsecamente ideológica; e, por último, que o objeto de uma ciência social é essencialmente qualitativo.

Quanto à historicidade do objeto, foi considerado neste trabalho o constante dinamismo e o potencial do objeto para ser transformado. Minayo (2000) afirma que o objeto em ciência social possui consciência histórica; assim, ele se desenvolve em um processo histórico e dinâmico que o remete às relações concretas da realidade. Quanto à identidade entre sujeito e objeto da pesquisa social, pode-se afirmar que aquilo que é pesquisado (em especial, os seres humanos e suas relações) e o próprio pesquisador "têm um substrato comum que os tornam imbricados" (Minayo, 2000).

A pesquisa social, quanto à sua qualidade ideológica, difunde idéias, interesses e visões de mundo historicamente construídas, dominantes ou não. É por este motivo que o pesquisador, por mais que busque a neutralidade e o distanciamento do objeto, acaba reproduzindo a ideologia da realidade que ele conhece - fato observado nesta pesquisa.

Quanto ao caráter qualitativo do objeto de estudo, conforme Lênin (apud Minayo, 2000), a realidade social é mais rica do que qualquer teoria ou qualquer idéia que o pensador possa ter sobre ela, já que uma idéia tende a dividir, fragmentar e diferenciar os momentos e os objetos apresentados pela realidade. As categorias analisadas trazem uma carga ideológica, histórica, política e cultural que não pode estar contida apenas num dado numérico, ultrapassando a análise quantitativa (Minayo, 2000).

Este trabalho tratou seu objeto de análise qualitativamente, buscando ultrapassar os dados numéricos e as estatísticas utilizadas, com vista à aproximação da realidade em sua constituição sempre complexa, contraditória e inacabada, isto é, em constante transformação. Tendo em vista a análise dialética, o método adotado se realizou como "o próprio processo de desenvolvimento das coisas" (Minayo, 2000). Trata-se, mais especificamente, do método histórico-estrutural que privilegiou, de forma 
equiparada, os aspectos históricos, envolvendo as ações dos sujeitos, e os estruturais, preexistentes ou independentes das ações dos sujeitos, da questão estudada. Optou-se, assim, pela apreensão dos fatos dialeticamente relacionados, compreendendo as determinações fundamentais, as contradições, a heterogeneidade e a complexidade do objeto de estudo.

A pesquisa qualitativa como tentativa de uma compreensão detalhada das características e significados da realidade, busca alcançar o conhecimento teórico por meio da aproximação com o objeto de estudo, segundo Minayo (2000). Abstrair do mundo material para o mundo teórico pode ser uma tentativa de representar a realidade no conhecimento, o que pode vir a se tornar um problema devido à dinâmica de transformação constante da realidade. Entretanto, a análise qualitativa aqui realizada buscou ultrapassar a aparência e desvendar a essência do objeto.

Privilegiando a reflexão crítica do referido objeto, esta pesquisa assumiu-se predominantemente teórica, valendo-se de material bibliográfico disponível em diferentes fontes documentais produzido por autores de interesse para o estudo. As fontes de informação selecionadas consistiram nas referências bibliográficas específicas do tema como livros, periódicos, jornais e revistas de divulgação cultural e científica. Também foram captadas informações em entrevistas de autores versados no tema já publicadas em veículos de comunicação de ampla divulgação nacional e pela participação em eventos científicos de interesse para a pesquisa.

Inspirada em Moraes (2001), ainda foi utilizada uma técnica de coleta de dados em fontes secundárias, denominada entrevista simulada ou indireta. Trata-se de tomar pensamentos importantes de autores contidos em livros, artigos, depoimentos e entrevistas diretas concedidas a outros investigadores, como respostas a perguntas feitas pelo pesquisador. Diferente da análise de conteúdo, nesta técnica, as perguntas elaboradas previamente orientam a seleção dos trechos mais relevantes do autor contidos no material estudado. Tal técnica foi utilizada principalmente com os autores: Hayek, tendo como fonte o livro "O caminho da servidão", Sader, em entrevistas e pequenas publicações no jornal Folha de São Paulo, entre 2003 e 2006, e Chesnais, em entrevista concedida aos jornais Folha de São Paulo e O Globo, entre 2004 e 2006.

Foram analisados os principais programas sociais do governo Lula, sendo estudados com mais detalhes os programas Bolsa-Família e de Microcrédito, buscando apreender a realidade além do visível e entendendo as contradições e conflitos do seu percurso, como requer a análise qualitativa - dialética. O programa Bolsa-Família foi 
escolhido por se tratar do programa que alcançou maior repercussão, atingiu o maior contingente de beneficiários das políticas de transferência de renda da história do país, fazendo parte do Fome Zero, a principal promessa de governo na eleição do presidente Lula em seu primeiro mandato como medida prioritária de combate à fome e à pobreza.

A escolha do Microcrédito, programa integrante da política de Economia Solidária do governo, deveu-se à sua propagação crescente no mundo e recentemente no Brasil, aliada à expansão da Economia Solidária que se auto-denominou a alternativa mais viável aos efeitos deletérios da economia capitalista, segundo Paul Singer (2001). Além disso, o Microcrédito estimula a geração de renda e tem por objetivo atender aos mais pobres, tendo sido impulsionado pelo professor Muhammad Yunus por meio da criação do Grameen Bank, em Bangladesh, que proporcionou mais oportunidades sociais pelos empréstimos aos desempregados. Esta iniciativa cresceu a ponto de se espalhar por todo aquele país, influenciando no novo tipo de sistema bancário adotado em outros países, inclusive culminando no Prêmio Nobel da Paz 2006 a Yunus. 


\section{REFERENCIAL TEÓRICO}

Um autor de referência para este estudo foi Perry Anderson que, em "Balanço do Neoliberalismo" (1995), precisou, de forma clara, a origem e o significado do pensamento neoliberal no mundo. A esse respeito também foram utilizados Teixeira (1996), Antunes (2004), Chesnais (1996) e Meszáros (2002), autores que fizeram críticas radicais ao neoliberalismo, com base nas suas conseqüências negativas para o bem estar sócio-econômico de parcelas significativas da população, bem como para a sua cidadania.

O neoliberalismo, ou novo liberalismo, surgiu logo após a II Guerra Mundial baseado em idéias liberais do século anterior. Segundo Perry Anderson (1995), foi um fato distinto do liberalismo clássico. Entretanto, o neoliberalismo não pode ser simplesmente entendido como um fenômeno recente ou um modelo de governo hegemônico no capitalismo atual. Por este motivo, a definição adotada neste trabalho dá espaço à reflexão da formação histórica do neoliberalismo no panorama mundial desde suas raízes no segundo pós-guerra, ancorada nas idéias de Hayek. Como doutrina econômica, política e ideológica, o neoliberalismo é, de fato, um pensamento que defende a ausência ou intervenção mínima do Estado na economia.

Segundo Perry Anderson (1995), o neoliberalismo "foi uma reação teórica e política ao Estado intervencionista e de bem-estar", tendo as suas origens em 1947 na reunião de Monte Pèlerin, na Suíça, realizada pelos pensadores liberais da Escola austríaca ${ }^{1}$. Seu principal impulsionador foi Friedrich Von Hayek, que escreveu a primeira obra neoliberal mais marcante, em 1944, intitulada "O Caminho da Servidão". Nesta obra, Hayek (1977) desferiu ataques à proteção social do Estado de bem-estar, sobre o qual afirmava ser o próprio "caminho da servidão", chegando a compará-lo ao socialismo e ao nazism, por considerar em ambos um "caráter totalitário" na restrição das liberdades individuais.

Hayek (1977) e os defensores do neoliberalismo acreditam que se um indivíduo depende do Estado para satisfazer suas necessidades de alimentação, por exemplo, tem a sua liberdade reduzida. O Estado se torna arbitrário e se perde na relação entre indivíduo e Estado o aspecto democrático. Em outras palavras, o indivíduo

\footnotetext{
${ }^{1}$ A Escola Austríaca era uma corrente de pensamento econômico que defendia uma menor intervenção do Estado na economia, tendo como base o princípio de que quanto menor essa intervenção, maior a eficiência econômica e, conseqüentemente, maior o bem-estar e a liberdade dos indivíduos que compõem uma sociedade.
} 
sendo alimentado pelo Estado, estando numa relação de dependência, não se revolta contra este e jamais reivindica sua liberdade, o que também contraria o princípio liberal da competitividade, pelo qual, idealmente, o indivíduo se esforçaria mais para sobreviver e alcançar sucesso na competição por melhores espaços, principalmente no mercado de trabalho.

Além disso, o Estado de Bem-Estar é perdulário (Hayek, 1977), segundo o neoliberalismo. Condenando os custos do bem-estar social aos cofres públicos, o ideário neoliberal também culpa o beneficiário da proteção social do Estado, afirmando que o pobre é oneroso ao governo, pois se acomoda na dependência e não procura sustentar-se sozinho por outros meios. É como se o Estado de Bem-Estar com todo seu aparato de proteção social, contribuísse para o aumento da pobreza, ou como se a situação de pobreza fosse a mais cômoda e agradável ao indivíduo.

Milton Friedman, continuando o legado neoliberal, foi um dos discípulos de Hayek nos Estados Unidos que esteve presente na reunião de Monte Pèlerin. Reconhecido entre os pensadores da Escola de $\mathrm{Chicago}^{2}$, Friedman acreditava que a solução para a prosperidade da sociedade estava num sistema de concorrência e liberdade absoluta (Anderson, 1995). Com seu empenho na defesa intransigente da economia de mercado, chegou a ganhar o prêmio Nobel de Economia de 1976.

Em suas primeiras tentativas, nas décadas de 1950 e 60, o neoliberalismo não se mostrou convincente, pois apareceu numa fase em que o capitalismo estava no auge do seu Estado de Bem-Estar ${ }^{3}$. Na época em que se deu a crise do petróleo, exatamente em 1973, segundo Anderson (1995), inicia-se a grande crise do modelo econômico do pós-guerra, fato que deu margem à entrada das idéias neoliberais na cena política.

O primeiro país a implantar o neoliberalismo foi o Chile, na ditadura de Pinochet, experiência que interessou os governos Tatcher, na Inglaterra, e Reagan, nos Estados Unidos, que incorporaram o projeto neoliberal na década seguinte (Anderson, 1995). Reconhecendo nos governos de Margareth Thatcher (Reino Unido) e Ronald Reagan (EUA) a inauguração da era do neoliberalismo no mundo, Chesnais (1996),

\footnotetext{
${ }^{2}$ A expressão Escola de Chicago refere-se a escolas e correntes do pensamento de diferentes áreas e épocas que ficaram conhecidas por serem discutidas e desenvolvidas na cidade norte-americana de Chicago. Na economia, a Escola de Chicago representa uma corrente que defende o livre-mercado.

${ }^{3} \mathrm{O}$ termo Estado de Bem-Estar foi criado por um bispo inglês, William Temple, que se referia ao estado de paz que sucedeu o período de guerra. Retirado de REGONINI, G. Estado do Bem-Estar. In: BOBBIO, N.; MATTEUCCI, N.; PASQUINO, G. Dicionário de política. 11. ed. Brasília: Editora Universidade de Brasília, 1998.
} 
assim como ao autor supra mencionado, afirma ser este o início de uma grande política de atração submissa dos outros governos ao capital financeiro.

A expressão ideológica do neoliberalismo tomou força no final do século XX, impulsionada pelas manifestações do liberalismo anteriores, desde o século XVII, coincidindo com a consolidação da dominação econômica da classe burguesa, na afirmação de Duarte (1997, p. 51). Os pressupostos liberais partem da compreensão de que o homem é um ser individual e tem certos direitos inalienáveis, principalmente no que se refere à liberdade individual. Os liberais, segundo Bobbio (1988, apud Duarte, 1997, p. 53) defendem muito mais o direito de propriedade, que, para eles, é indissociável do direito de liberdade.

Em termos de direitos, a classe burguesa liberal defendia não só os direitos civis, mas também os direitos políticos, que, na percepção de Duarte, era uma forma de defender seus privilégios e aumentar seus domínios. Portanto, a aceitação dos direitos pelos neoliberais restringe-se aos chamados direitos de primeira geração, ou direitos individuais, baseados na primazia da liberdade individual. Quanto à igualdade, referenciada nos direitos sociais, os neoliberais a vêem como utopia e consideram aceitáveis, e até naturais, as desigualdades entre os homens. Para o neoliberalismo, é natural e até necessário que exista a desigualdade, a pobreza e o desemprego para haver maior competitividade entre as pessoas e redução dos salários, o que, em última instância, favorece o lucro dos grandes capitalistas. Por isso, não consideram interessante existirem iniciativas estatais de redução da desigualdade social ou de combate à pobreza.

A liberdade defendida pelos neoliberais se estende ao mercado, daí a denominação "livre mercado", empregada pelos neoliberais, ao defenderem o chamado "laissez-faire" das leis mercantis ${ }^{4}$, levando-os a recusar a intervenção estatal por acreditarem na existência de uma "mão invisível" que regula o mercado como mágica. Daí parte a crítica de muitos autores, como Teixeira (1996), Pereira (2002) e Anderson (1995), ao pensamento econômico liberal, que apresenta inconsistência por superestimar

\footnotetext{
${ }^{4}$ A expressão "laissez-faire" (em português "não interfiram") representa um princípio defendido pelos economistas mais liberais que defendem que o Estado deve interferir o menos possível na atividade econômica e deixar que os mecanismos de mercado funcionem livremente. Na opinião dos economistas clássicos, entre os quais Adam Smith, o papel do Estado na economia devia limitar-se à manutenção da lei e da ordem, à defesa nacional e à oferta de determinados bens públicos que o setor privado não estaria interessado (tais como a saúde pública, o saneamento básico, a educação, as infra-estruturas de transporte, etc).
} 
a produção de valores de troca, para a extração de mais-valia e a acumulação de riquezas, isentando-se da satisfação das necessidades humanas.

Para os (neo)liberais, as saídas para a satisfação das necessidades humanas encontram-se apenas no mercado, que se abre aos esforços empreendedores de indivíduos isoladamente, dependendo das habilidades e capacidades individuais desenvolvidas por cada um. Por esta razão, os críticos do neoliberalismo sustentam que o individualismo, o egoísmo e a culpabilização das pessoas por seu "fracasso" na satisfação de suas necessidades, foram tendências acirradas pela ofensiva neoliberal.

Francisco Teixeira (1996) discutiu com brilhantismo o surgimento do neoliberalismo e sua influência sobre as políticas sociais no capitalismo. Este autor explicou como se formou a teoria liberal, qual vem sendo o papel do Estado na lógica neoliberal, como esta teoria utilizou o mercado para institucionalizar o neoliberalismo mundialmente e de que forma este modo de acumulação afeta a política social.

Quanto à forma histórica original do liberalismo, Teixeira (1996) afirma que o nascimento do liberalismo se remete a um corpo de formulações que defendem o Estado em sua função constitucional e jurídica, ou seja, estabelecendo um conjunto de leis que permitam a coexistência da liberdade de um com a dos outros. Dentre as idéias centrais da teoria clássica do liberalismo, o autor revela que essa teoria é muito mais uma exigência do que deveria ser a sociedade, do que uma análise estritamente empírica da realidade de então. Para Teixeira (id), "contra o abuso do poder estatal, quer na esfera da administração da sociedade, quer na esfera da economia, todos os teóricos liberais defendiam um governo limitado", um Estado de direito que não se intrometesse nas questões econômicas e sociais da sua nação. Mas, este modelo de governo só ganha espaço na prática a partir de meados do século XIX, quando se inicia a fase liberal do capitalismo que se estende até a Crise de $1929^{5}$.

A saída para a Crise de 1929, conforme Teixeira (id), foi o capitalismo regulado pelo Estado, pautado no "modelo social-democrático de desenvolvimento" que vigorou entre as décadas de 1940 (pós-guerra) e 1970, com a vigência do Estado de Bem-Estar Social, sustentado pela idéias de Keynes e Beveridge ${ }^{6}$. Mas, no início dos

\footnotetext{
${ }^{5}$ A Crise de 1929, também chamada por vezes de Grande Depressão, foi uma grande recessão econômica que teve início em 1929 e que persistiu ao longo da década de 1930, terminando apenas com a Segunda Grande Guerra. Este período de recessão econômica causou altas taxas de desemprego, quedas drásticas do produto interno bruto de diversos países, bem como quedas igualmente drásticas na produção industrial, preços de ações, e em praticamente toda atividade econômica, em diversos países no mundo.

${ }^{6} \mathrm{O}$ Estado de Bem-Estar assegurava o pleno emprego, redistribuía a renda, contando com um Imposto de Renda altíssimo que cobria os gastos com seguridade social, eliminando a pobreza absoluta. O Estado de Bem-Estar é melhor explicado mais adiante, neste trabalho, na explicitação da categoria política social.
} 
anos 1970, ocorreu uma grande crise econômica, já mencionada acima, que abalou o Estado de Bem-Estar, aumentando as taxas de inflação e diminuindo e os índices de crescimento. Com isso, as condições se mostraram favoráveis à propagação do ideário neoliberal. Havendo um abalo efetivo do Estado de Bem-Estar Social, ou do Welfare State, no fim dos anos 1970, espalhou-se a crença neoliberal de que as políticas sociais publicas estavam em extinção.

Em consonância com o pensamento de Anderson (1995), Teixeira (1996) reconhece que a reestruturação produtiva trazida pelo neoliberalismo como resposta à crise mencionada, provocou significativa mudança nas relações de trabalho inclusive no gerenciamento da força de trabalho. Além disso, foi o neoliberalismo quem impulsionou a entrada do capital financeiro que, para Chesnais (1996), cobra o seu preço de várias maneiras. Ao caracterizá-lo, o autor avança no tema afirmando que este regime:

"já não aparece apenas na forma "ingênua" de dinheiro emprestado a juros. Alimenta-se da enorme soma de recursos depositados nos sistemas privados de aposentadoria, valoriza-se aplicado em títulos da dívida pública dos países e, cada vez mais, no mercado de ações. Atrai o caixa das grandes empresas e as reservas de milhões de famílias. Transfere-se de um país para outro, sem barreiras, sempre em busca de maior rendimento. Bate em retirada, deixando um rastro de crise, quando julga que as condições já não lhe são tão favoráveis."

O favorecimento do capital financeiro pelo neoliberalismo se pauta na valorização máxima em curto prazo, independente de suas conseqüências negativas em vários campos, como no mercado de trabalho, saindo de cena nos momentos de "crise". Chesnais (1996) aponta as três principais características ou fragilidades deste regime que semeiam a miséria mundial. São elas: a) a falta de um compromisso social, promovendo exclusão e marginalização, já que sua viabilidade está no crescimento econômico através da desigualdade; b) a dificuldade de internacionalização integradora, fazendo com que o abismo entre o centro e a periferia se alargue cada vez mais; c) a grande vertigem do regime financeirizado, que pressupõe a existência de um sistema em que os Estados Unidos são o centro único e, o dólar, a moeda internacional inigualável.

Independente da denominação ou da forma que assuma, (neoliberal, imperialista, financeiro), a lógica inerente ao capital traz prejuízos à sociedade. Chesnais (1996) e Meszáros (2002) apresentam pensamentos convergentes ao tratar da lógica do capital e sua produção destrutível, em que "a destruição da natureza é justificada pela produção de mercadorias para o bem-estar humano" (Meszáros, 2002). Em conseqüência, Meszáros (2002) fala de uma crise endêmica, crônica e permanente, fazendo emergir o 
espectro da destruição global da humanidade. Desta forma, ambos os autores afirmam que as reformas do capitalismo serão cada vez mais difíceis.

Discípulo de Meszáros, Ricardo Antunes, tratando especificamente do significado do neoliberalismo no Brasil, defendeu a tese de que, no Brasil, houve a “desertificação neoliberal” desde a década de 1990, com a entrada desta doutrina nas frentes governistas, até os anos 2000. A primeira reforma do governo Lula, segundo Antunes (2004), foi no funcionalismo público, um grande golpe para os trabalhadores. Ele se indaga porque o presidente Lula deu continuidade ao neoliberalismo, havendo consenso, antes de sua posse, que tal orientação para o governo brasileiro não seria eficaz para a resolução dos problemas internos do Brasil, o que me parece um questionamento correto na comparação entre as promessas iniciais do presidente e o que vem sendo feito na prática.

A obra de Antunes é relevante para esta monografia, pois, em 2003, ao escrever sobre a vitória de Lula, que teve significado simbólico expressivo real, o autor ainda acreditava que o novo presidente poderia suplantar o neoliberalismo. Entretanto, depois de um ano de governo, sua posição modificou-se, pois Antunes acreditava que o governo estava retro-alimentando a receita de bolo do neoliberalismo e que, na verdade, “o governo Lula dá continuidade ao neoliberalismo" (p. 134).

Pereira (2005 e 2002) e Sposati (1999) contribuíram para este estudo no tratamento dado à relação entre o neoliberalismo e as implicações deste para as políticas sociais e econômicas, em especial, no Brasil. Pereira (2002) faz um resgate histórico da política social no mundo assim como da intervenção estatal na área social em vários períodos face à satisfação de necessidades básicas dos indivíduos, inclusive no contexto brasileiro.

Pereira (2000), ao analisar o neoliberalismo, considera que as suas promessas de resolver a questão do crescimento econômico, distribuir melhor bens e serviços via mercado, promover por meio de políticas sociais auto-sustentadas o empoderamento individual e a melhoria dos níveis de bem-estar da maioria da população foram falaciosas. A autora afirma que a doutrina neoliberal "aprofundou as desigualdades sociais, desmantelou grande parte dos direitos sociais consolidados, além de reabrir tensões e violências que estão na origem da velha questão social" (2000), destacando o retrocesso das conquistas sociais e políticas de parcela considerável da população.

Em concordância com esse pensamento de Pereira, Sposati (2002) ainda afirma que com o enquadramento ao neoliberalismo e sua cultura privatista, a categoria 
trabalho (e seus direitos) perdeu lugar para a categoria mercado, impactando sobre os países de forma a distanciar a relação entre direito social e política social, o que não atende às condições reais de vida das pessoas.

Os pensadores que analisaram o neoliberalismo e o capitalismo contemporâneo constataram a repercussão das políticas neoliberais na realidade econômica e social das populações mundiais. A globalização mundial, a vinda da informática, o avanço das telecomunicações, as mudanças profundas nas relações de produção, também se inserem na realidade como fatores que provocaram mudanças que, de acordo com Vieira (1997), evocaram tendências à queda do Estado-Nação, à globalização da pobreza e do desemprego, que tornou desnecessária boa parte dos moradores do planeta.

Apesar dos países que adotaram o neoliberalismo combaterem as altas taxas de inflação e aumentarem as taxas de lucros das indústrias, não alcançaram taxas altas de crescimento econômico, como existia antes da crise do Estado de Bem-Estar, e apenas aumentaram o grau de desigualdade com a queda dos salários e o crescimento do desemprego. Com a introdução do neoliberalismo, os países recuperaram os lucros da época do auge do capitalismo, mas não recuperaram os investimentos ou o capital produtivo, o que reduziu seu crescimento econômico. Este fato é explicado por Anderson (1995) como uma conseqüência da desregulamentação financeira que criou condições extremamente propícias para o capital especulativo.

As políticas sociais do Estado neoliberal servem de instrumentos para o capital. Assim, ocorre um tipo de privatização das políticas sociais, já que a responsabilidade pela prestação dessas políticas é transferida para a esfera privada: 0 voluntariado. Segundo Pereira (2003), o Estado se mostrou ineficaz em suas tentativas de erradicar a pobreza, incentivando, assim, a expansão do voluntariado. A ideologia neoliberal desincentiva o exercício da cidadania social por meio de ações voluntárias. As políticas sociais públicas passam a se focalizar na extrema pobreza, utilizando critérios de seleção rigorosos e estigmatizantes de beneficiários. A focalização das políticas públicas é captada por seus beneficiários como vergonha, incapacidade e punição, já que, de acordo com o ideário neoliberal, desempregados, pobres, mendigos, idosos se mostram incompetentes na condução de suas vidas e incapazes de prover seu sustento e de sua família, não se adaptando à ordem social vigente.

A desregulamentação do mercado de trabalho trouxe outras implicações cruéis às massas trabalhadoras dos países neoliberais. A ética capitalista do trabalho incentiva 
o empregador a incorporar novas tecnologias para produzirem mais com menos trabalhadores e acumularem capitais. O trabalho está desaparecendo no sentido tradicional do termo e o desemprego estrutural está sendo inevitável, como assinala Schaff (1993). A estrutura do processo social de produção foi transformada e excluiu muitos trabalhadores do processo produtivo, em vez de produzir empregos que, segundo o pensamento neoliberal, dignificam o homem.

As maiores conquistas dos movimentos trabalhistas, durante todo o século $\mathrm{XX}$, foram os direitos sociais. Com a entrada do neoliberalismo no país, evidenciou-se um ataque estratégico aos movimentos populares e sindicatos e o desmantelamento dos direitos, pois inclusive os direitos passaram a ser vistos na relação entre Estado e mercado. Sorrateiramente o neoliberalismo promoveu a desconstrução de políticas que garantem direitos previstos nas leis, enfatizando o direito adquirido pela compra. $\mathrm{O}$ mercado negou o Estado, mas não foi capaz de responder com sensibilidade às necessidades sociais, apresentando-se de forma elitista e orientada para os não necessitados. Utilizadas para manter a situação de pobreza e submissão das classes populares, as políticas de seguridade social privilegiam o assistencialismo, acentuando a desigualdade e degradando a cidadania.

Os direitos trabalhistas edificados pela classe trabalhadora foram flexibilizados com a desregulamentação do mercado de trabalho. Com a existência de taxas de desemprego alarmantes, o trabalhador passou a submeter-se a trabalhos mais precários, mesmo tendo melhor qualificação que o exigido, e os contratos de trabalho passaram a oferecer condições mais favoráveis ao patrão, como a extensão das jornadas de trabalho, a perda dos vínculos empregatícios e dos direitos legais, como as formalidades da carteira assinada. Segundo Sader (2003), a superexploração do trabalho acontece porque a oferta de mão-de-obra é maior que os empregos existentes. Assim, os trabalhadores acabam recebendo salários abaixo do mínimo necessário. No caso do Brasil, Sader afirma que o salário deveria ser cinco vezes maior que o salário mínimo vigente para atender às necessidades das famílias brasileiras.

Emir Sader (2003), autor que aprofunda a discussão sobre o Governo Lula desde a vitória nas urnas em 2002, trouxe grande contribuição ao presente trabalho ao investigar o Brasil de Lula elucidando seus desafios, suas conquistas e seus limites diante do neoliberalismo, incorporando os fatores históricos, políticos e sociológicos da questão. Sader (2003), anteriormente, ainda investiga o governo FHC e seus rumos neoliberais no país. 
Este autor (idem) colabora para a realização deste trabalho por meio da crítica ao modelo econômico socialmente degradante de FHC, que ele denomina de "pesada herança" do Brasil pós-Cardoso. Além disso, condena a atitude do governo FHC ao não dar cumprimento às suas promessas da fase de eleição, o que ficou claro principalmente pela fragilidade da economia e pela persistência da má distribuição de renda no país.

Apesar da realidade do pós-Cardoso, Sader (id.) reforçou a possibilidade de ruptura com a entrada da esquerda no poder, acreditando que o governo Lula seguiria pelo caminho do "antineoliberalismo" ou "pós-neoliberalismo", ainda que se deparasse com desafios resultantes das políticas neoliberais, como a precarização da força de trabalho e a fragilidade das políticas brasileiras de proteção social.

Porém, antes da análise do Governo Lula, convém elucidar os conceitos e as categorias trabalhadas na construção desta pesquisa, apresentados na próxima seção. 


\subsection{Categorias Analíticas}

\section{a) Neoliberalismo}

O neoliberalismo consiste no mesmo ideário do liberalismo, só que com nova roupagem. É fenômeno advindo da Europa e da América do Norte em reação ao Estado de Bem-Estar do segundo pós-guerra, segundo Anderson (1995). Posiciona-se contrariamente a qualquer ameaça do Estado na limitação dos mecanismos de mercado, justificada pela defesa da liberdade econômica e política dos cidadãos. Ganhou força a partir da década de 1970, com a crise do Estado de Bem-Estar dadas as altas taxas de inflação e baixo crescimento econômico.

O neoliberalismo surgiu como uma alternativa ao Welfare State keynesiano, propondo solução para as crises fiscal e inflacionária, por meio da desregulamentação do mercado financeiro e a abertura dos capitais nacionais à globalização. O programa neoliberal enfatizou, como já visto, a competição, a liberdade individual, a liberdade do mercado e a estabilidade monetária e a diminuição da intervenção estatal como as metas para suas políticas. Seguido por outros países, o primeiro governo neoliberal aconteceu no Chile, segundo Anderson (1995). Os governos neoliberais que o copiaram foram os da ex-primeira-ministra Margareth Tatcher, na Inglaterra, e o de Ronald Reagan, nos Estados Unidos, nos anos 1980, impulsionando sobremaneira o neoliberalismo na construção das políticas sociais mundiais, vigentes em muitos países até os dias atuais.

A categoria neoliberalismo remete a características essenciais reconhecidas por diversos autores, como Pereira (2002), Anderson (1995), Duarte (1997), Luz (2004) e Teixeira (1996), cuja aplicação se dá por meio de um conjunto de procedimentos nos países que adotaram o neoliberalismo, assim especificado: a) livre mercado, acima de todas as outras formas de organização da sociedade; b) individualismo; c) liberdade medida pela desigualdade; d) privatizações e a desregulamentação econômica.

Pelos seus pressupostos, o mercado tem função central, reduzindo a ação estatal ao mínimo (o Estado como mero agente fiscalizador e como impulsionador momentâneo da população fora do mercado) e pressionando a população à mercadorização de suas necessidades. Como já explicado acima, o mercado é entendido como a melhor forma de satisfação de necessidades e desejos das pessoas. Sendo assim, a lógica neoliberal atua de tal forma que pressiona os indivíduos a satisfazerem suas 
necessidades e desejos no mercado, já que este é de livre acesso a todos e o esforço individual é o único fator de importância para uma efetiva satisfação, não interessando outras questões como habilidades e oportunidades.

O individualismo, além de moral é um conceito político e social que preconiza a liberdade de afirmação individual sobre um grupo, especialmente no que diz respeito à propriedade privada. Em suma, o individualismo se manifesta "não como uma busca de distinção", como afirmou Simmel (1998, p. 110), mas como oposição a qualquer tipo de autoridade ou forma de controle sobre o indivíduo. A auto-afirmação do indivíduo com relação à sociedade foi valorizada nos países em que o desenvolvimento do capitalismo se deu pelo neoliberalismo, tendo se perdido o sentido do coletivo.

Na sociedade neoliberal, segundo Teixeira (1996), a sociabilidade é construída centrada no interesse próprio e no egoísmo, como qualidades inatas dos indivíduos. A lógica neoliberal compreende que, no momento em que cada qual cuida de si, todos têm suas necessidades satisfeitas e realizam o bem-estar de todos. O mercado tem fundamental importância para a ideologia neoliberal porque ela acredita que ele é o espaço para a satisfação de necessidades materiais e para a realização da liberdade econômica e política dos indivíduos. Os neoliberais acreditam cegamente na perfeição do mercado, em sua capacidade de se auto-regular e ativar mecanismos de coordenação inconscientes, o que não ocorre na prática, pois o mercado, por si só, não redistribui os recursos igualmente.

O ideário neoliberal ofereceu desde o início promessas e ajustes para os países que o adotaram. Duarte (1997, p. 55 - 65) apresenta algumas idéias que ganharam força durante a trajetória do neoliberalismo. Uma destas idéias refere-se ao papel do Estado na ordem social. A grande crítica neoliberal ao Estado interventor identifica certas ações protetivas desnecessárias que o tornam ineficiente, perdulário e paternalista, abusando na arrecadação de impostos e causando crises. O ideal seria um Estado com mínima participação no setor produtivo e politicamente forte, reduzindo as despesas públicas para saída de qualquer "crise".

Considerando as taxas de desemprego naturais e uma variável fora das atribuições do Estado, os neoliberais defendem o fim do auxilio desemprego e a domesticação dos sindicatos. Em seguida, será apresentada a segunda categoria analítica deste trabalho: política social. 


\section{b) Política Social}

A política surge com a intenção de dissipar conflitos entre diferentes interesses presentes nas relações sociais. Toda política é uma forma de consenso entre indivíduos e grupos. Entretanto, a política aqui é compreendida, nos termos de Pereira (2005), diferente do sentido clássico empregado para designar partido, voto, eleição, governo. Compreende ações do Estado, geralmente demandadas pela sociedade, visando o atendimento de necessidades sociais. Como afirma Sposati, (1999), "as políticas sociais revelam o empenho de uma sociedade em afirmar um patamar de civilidade".

As ações de uma política social - um tipo de política pública para Pereira (2005) - devem convergir, portanto, para o atendimento de necessidades humanas que não se restrinjam às dimensões biológicas de mera sobrevivência, objetivando a concretização de direitos sociais - direitos esses que são tão legítimos quanto os outros (direitos civis e políticos). Partindo do significado de público, originado do latim res publica (= coisa de todos), a política pública para Pereira (2005) é uma forma de organização política que, além de uma ação ou "não-ação" de iniciativa do Estado, deve ter a participação da sociedade para tornar-se legítima e representativa. A intervenção do Estado é de fundamental importância ainda que as iniciativas privadas exerçam influência sobre o Estado.

A palavra "política", na língua portuguesa, diz respeito tanto ao processo eleitoral de competição por cargos e negociação de interesses na sociedade quanto à implementação de ações governamentais específicas, em diversos setores específicos, como saúde, meio ambiente, redução da pobreza, educação. Os pensadores da língua inglesa usam palavras diferentes para estes dois significados, "politics" no primeiro uso, e "policy" no segundo.

Para o presente estudo, a política social (policy para os ingleses) reflete as ações do Estado e da sociedade executadas para concretizar direitos sociais de interesse público e para distribuir bens produzidos socialmente. A política social pública deve ser acessada por todos os membros da comunidade e de forma gratuita, segundo Pereira (2005), acesso este que não pode estar baseado na lógica do mercado. Para se compreender a política social atual, retomar-se-á a seguir a origem desta política como satisfação de necessidades, de forma a entender, com a contribuição de Polanyi (1980), como o conceito vem sendo construído desde então. 
$\mathrm{Na}$ história das políticas sociais de "satisfação de necessidades" (Pereira, 2002), a primeira iniciativa de impacto aconteceu em 1536, quando Henrique VIII promulgou, na Inglaterra, a Poor Law, pela qual se instituía uma contribuição compulsória, recolhida pelo erário, denominada taxa de caridade. Em 1601, Elizabeth I da Inglaterra assinou a Segunda Poor Law, legislação especial voltada para os necessitados. Em 1834, esta legislação foi anulada pela Poor Law Reform. Porém, temse entre 1795 e 1834, período considerado como o mais ativo da revolução Industrial na Inglaterra, a Speenhamland Law, buscando impedir o mercado de trabalho regulado pela lei da oferta e da procura.

A Speenhamland concedeu, pela primeira vez, o abono sob a forma de adicionais aos salários dos trabalhadores de acordo com uma tabela que dependeria do preço do pão (Polanyi, 1980). Isso se deu para assegurar aos pobres uma renda mínima independente dos seus proventos. Esta renda mínima, chamado "direito de viver", conseguiu impedir um mercado de trabalho competitivo ao mesmo tempo em que evitou o trabalho forçado em troca de proteção, alimentação e abrigo.

Em 1832, de acordo com Polanyi (1980), com a classe média ensaiando seu caminho em direção ao poder, em parte para ultrapassar o obstáculo da intervenção social estatal à nova economia capitalista, tem-se o "direito de viver" revogado, sob o argumento de que a Speenhamland provara estar equivocada por não propiciar um salário universal que respondesse aos interesses dos trabalhadores assalariados, entre outros. Logo, acompanhado da Reform Bill (1832) e da Poor Law Amendment Act (1834), inicia-se o capitalismo moderno inglês e mundial, bem como o fím dos abonos. Estas últimas leis ressaltavam a deterioração da capacidade produtiva das massas, impondo, assim, o fim do direito incondicional do pobre à assistência social.

$\mathrm{Na}$ Inglaterra, as cidades eram superpopulosas, sujas e as condições de vida dos trabalhadores eram degradantes no auge da chamada revolução industrial, no século XIX. Situações absurdas se tornavam corriqueiras com o aumento do desemprego, do crime e da mendicância. Substituindo as anteriores, foi criada a Nova Lei dos Pobres de 1834, que determinava o abrigamento em Casas de Trabalho (workhouses) a todos os que recorressem ao Estado em busca de alguma assistência e fossem "incapazes para o trabalho" (Polanyi, 1980). Estas instituições abrigavam temporariamente geralmente os desempregados e os "inválidos" (impossibilitados de trabalhar), que em troca de refeições e um abrigo pouco confortável, onde oravam e trabalhavam às vezes mais duramente que nas fábricas, sendo firmemente controlados. Esse rígido controle era 
explicado como forma de incentivo à busca de emprego. Instituições como estas surgiram no período tentando tornar a pobreza algo rentável para a classe dominante. A realidade da pobreza, distante do alcance da imaginação da burguesia, era vista como uma vantagem para o progresso, a ponto de a burguesia propor a exportação dos pobres "excedentes" para o trabalho nas colônias inglesas.

A Poor Law Reform, surgiu com a transição da economia auto-regulável para a de mercado e promoveu a expansão para um mercado de trabalho competitivo dado o fim do paternalismo estatal sobre os pobres. Contudo, cabe ressaltar que talvez esse paternalismo, em forma de leis para os pobres, pudesse ser um meio de regulamentar normas trabalhistas inicialmente, já que, em 1836, o movimento Cartista procurava, por meio da participação proletariada na política, instituir alguma forma de assistência aos trabalhadores, como vinha sendo anteriormente implantado ou como o socialista utópico Robert Owen instituiu em sua fábrica ${ }^{7}$.

A partir da perda do "direito de viver", a proteção social pública ficou reduzida, o que foi justificado por diversos pensadores à época; e, segundo Pereira (2002), fortaleceu o ideário liberal. Isso porque, sob o pretexto de resguardar a liberdade e a independência do indivíduo contra a tutela do Estado, intelectuais, como Thomas Malthus, repudiaram a intervenção estatal. "Estas justificações fortaleceram sobremaneira a ideologia liberal, que relacionava o trabalho às liberdades negativas ${ }^{8} \mathrm{e}$ via o indivíduo como detentor de um direito natural à liberdade, oposto ao direito artificial à proteção institucionalizada". (Pereira, 2002, p. 106). O único tipo de intervenção aceita poderia ser feita sem qualquer obrigação, no sentido de ensinar aos pobres a adaptarem-se à ordem social, e eles próprios se ajudarem, sem jamais se acomodarem.

Pereira afirma que a partir deste momento em que o Estado tornou-se o "algoz" dos pobres, começaram a aumentar as experiências de auto-ajuda entre os trabalhadores, como as "friendly societies", mantidas pelos próprios trabalhadores, garantindo uma proteção social mínima, além de iniciar a luta dos operários por uma legislação que lhes protegesse dos abusos do capitalismo liberal. Mas, a história

\footnotetext{
${ }^{7}$ Informações adquiridas através do artigo Introducción histórica a la filosofia del Estado: los precursores del socialismo moderno, dos autores Léon, Segura e Galacho, disponível em 17/11/2006 no sítio http://laberinto.uma.es/Lab3/varios.pdf.

${ }^{8}$ A liberdade negativa do indivíduo tem como único pré-requisito "estar livre de" qualquer tipo de constrangimento ou arbitrariedade, enquanto a liberdade positiva significa "estar livre para", quer dizer, ter condições para acessar seus direitos fundamentais. Retirado de Revista Lua Nova no.62 São Paulo, 2004.
} 
mostrou que as conquistas dos trabalhadores só adquiriram maior respeito e relevância no século XX, como assinalou Rosanvalon (apud Pereira, 2002). O debate político e a força conquistada pelos trabalhadores estimularam os pensadores reformadores, como os fabianos ${ }^{9}$, que propuseram pequenas reformas econômicas e sociais estimulando o que Pereira chama de um "liberalismo mais social" (2002, p. 110), institucionalizado pelo primeiro ministro da Inglaterra Lloyd George devido às pressões dos trabalhadores. Além da lei de assistência aos idosos, George introduziu, entre 1911 e 1923, uma série de seguros, contribuindo para a construção da Seguridade Social por Beveridge na GrãBretanha, que influenciou o Welfare State mundial, após a Segunda Grande Guerra.

Contudo, no século anterior, Pereira (2002) assinala que já se tinha uma experiência de seguro social na Alemanha, o modelo bismarckiano, introduzindo a lei de acidentes de trabalho, o reconhecimento dos sindicatos, o seguro de doença, acidente ou invalidez, entre outras ações. Mas o modelo beveridgiano contemplava uma conotação de seguridade social mais abrangente que o bismarckiano, oferecendo serviços sociais gratuitos como: saúde, habitação, educação, emprego, assistência aos idosos, crianças e inválidos. O Welfare State, referenciado no pleno emprego (masculino) da doutrina keynesiana ${ }^{10}$, representou avanço para o campo das políticas sociais. A proteção social se desenvolveu nesse período de tal forma que promoveu a garantia do acesso a bens e serviços por meio de políticas sociais universais e proteção ao trabalho; daí Pereira intitular o período de "a fase de ouro das políticas de proteção social" (2002, p. 112), por 30 anos, até a década de 1970.

Embora a política social de viés neoliberal desvalorize os direitos, Pereira (2005) estabelece como condição para definir política social uma relação estreita entre esta e direitos de cidadania, em especial os direitos sociais, definidos na próxima categoria.

\footnotetext{
${ }^{9}$ A organização reformista inglesa, Sociedade Fabiana, foi fundada em 1884 e seu nome vem do chefe militar romano Fábio Máximo (século III antes da nossa era), alcunhado «Cunctator» (o «Contemporizador») pela sua táctica de expectativa, evitando os combates decisivos na guerra. A Sociedade Fabiana compunha-se principalmente de intelectuais burgueses: cientistas, escritores, políticos (como Sidney e Beatrice Webb); negavam a necessidade da luta de classe do proletariado e da revolução socialista, assegurando que a transição do capitalismo para o socialismo só era possível pela via das pequenas reformas e mudanças paulatinas na sociedade.

${ }^{10} \mathrm{O}$ termo keynesianismo, que revolucionou o pensamento econômico na década de 30 , se refere à política baseada no pensamento do economista inglês John Maynard Keynes (1883-1946) que propunha solucionar o problema do desemprego pela intervenção estatal, desencorajando o entesouramento em proveito das despesas produtivas, por meio da redução da taxa de juros e do aumento dos investimentos públicos.
} 


\section{c) Direitos Sociais}

O significado dos direitos sociais pressupõe a compreensão dos diferentes tipos de direitos. Os direitos individuais, principalmente os direitos de propriedade, são as principais garantias defendidas pelos neoliberais. Os direitos dos indivíduos, tradicionalmente, eram conceito negativo: o cidadão era livre de algo, como perseguição, censura, prisão arbitrária ou coerção. Nos dias atuais, a categoria "direito" vem adquirindo um sentido reivindicatório, tornando-se um conceito positivo: direito de moradia, escola, hospital, aposentadoria, saúde etc.

Pisón (1998) faz uma importante distinção entre as três gerações de direitos, utilizando a visão geracional que agrupa os direitos segundo as circunstancias históricas que os determinaram. Desta forma, os direitos civis e políticos são os de primeira geração, seguidos dos direitos sociais, de segunda geração e, por fim, dos direitos difusos de terceira geração. Com esta divisão, Pisón (1998) reconhece os direitos individuais, os primeiros positivados na história, como aqueles baseados no princípio da liberdade, especialmente da liberdade negativa. Os direitos sociais, ou de segunda geração, foram fundados no princípio da igualdade e os direitos difusos, ou de terceira geração, baseados na fraternidade e na solidariedade.

A respeito dos direitos, a principal discussão realizada se dá no sentido de definir o agente interventor ou o ente que irá regulá-los e implementá-los. Assim, não basta compreender a origem dos direitos, mas, principalmente, de quem deve ser exigida a responsabilidade por prestar ou intervir em favor deles, em especial os direitos sociais, os que mais geram polêmica.

Os direitos tradicionais, ou individuais, foram criticados, especialmente pelo socialismo, por serem direitos meramente formais. Sendo assim, a desigualdade de classe a que pertencem os indivíduos de uma mesma sociedade impede que haja liberdade de acesso aos direitos civis e políticos por todos. Entretanto, os liberais, defensores convictos dos direitos tradicionais, criticaram duramente os direitos sociais que, para eles, prescinde de gastos e intervenção estatal, apesar de não haver um agente causador da desigualdade definido. A discordância dos direitos sociais pelos liberais se dá principalmente por sua implementação perdulária. Mas, a inconsistência das críticas liberais aos direitos sociais é rebatida por argumentos como os de Plant (2002).

Raymond Plant contempla em seu artigo "Can there be a right to a basic income?"(“Pode haver um direito à renda básica?”), uma discussão de importância 
fundamental para esta pesquisa ao incorporar a noção de liberdade positiva à discussão. A liberdade negativa, defendida pelos liberais, apresenta uma grande falha, diz ele, ao excluir da liberdade dois pré-requisitos fundamentais: a habilidade e os recursos imprescindíveis para o exercício da liberdade. Isto significa afirmar que "ser livre para fazer algo exige que se esteja apto a fazê-lo e que se tenha recursos apropriados para tal" (Plant, 2002). É por este motivo que o autor defende a intervenção do Estado na aplicação dos direitos sociais que facilitariam o acesso aos direitos individuais de liberdade dos sujeitos, defendida por neoliberais como Hayek.

Ao refutar os argumentos de Hayek contra os direitos sociais, Plant desconstrói as idéias desse autor sobre a naturalidade e a inevitabilidade da injustiça social, ao dar maior destaque às respostas da sociedade para o fenômeno da injustiça, ainda que sua ocorrência seja natural - idéia da qual ele discorda. Desta forma, Plant defende os direitos sociais em função da sua redistribuição de bens e serviços que, para ele, é imprescindível à justiça social.

Os direitos sociais, portanto, são o tipo de resposta mais desejável para as conseqüências econômicas do mercado, que, para Plant, ainda compreende uma responsabilidade moral. Mesmo que a injustiça não seja uma conseqüência intencional, Plant chama atenção para o fato de que as pessoas que entram no mercado em situação desfavorável, assim permanecerão; ou, com o tempo, ficarão em situação ainda pior do que quando entraram. Daí parte a argumentação do autor de responsabilizar a todos pela atenção aos mais necessitados por meio dos direitos sociais, inclusive defendendo que estes devam ser institucionalizados pelo Estado para que sejam ofertados permanentemente, exigidos e controlados pela sociedade.

Em verdade, Hayek e Plant concordam com em um ponto: a distribuição na sociedade entre ricos e pobres pelo nascimento é natural, não se trata de injustiça. Porém, a injustiça, para Plant, se encontra na forma como a sociedade e suas instituições lidam com esse fato. A garantia de que a justiça social será legitimada é a prestação de serviços sociais como direito social e obrigação pública, pois quando os serviços sociais são prestados como direitos não existe aí constrangimento, estigmatização do beneficiário ou favor do Estado ou da sociedade. Daí decorre a estreita vinculação entre direitos sociais e justiça social, acatada por este estudo.

Os direitos de terceira geração são os direitos da fraternidade ou solidariedade. São direitos fundamentais de terceira geração o direito à paz, ao desenvolvimento sustentável, à posse comum do patrimônio da humanidade, direito ao meio ambiente. 
Segundo Bonavides eles "tendem a cristalizar-se neste fim de século enquanto direitos que não se destinam especificamente à proteção dos interesses de um indivíduos, de um grupo ou de um determinado Estado. Têm primeiro por destinatário o gênero humano mesmo (...)" (1997). Por isso, também são denominados direitos difusos. A grande justificativa para a defesa dos direitos difusos está nos direitos das futuras gerações, pensamento ligado à idéia de preservação da espécie e de suas criações. Considerados direitos coletivos por excelência, a sua concretização depende de um esforço coordenado em nível mundial sem precedentes e ainda a ser realizado. 


\section{O NEOLIBERALISMO NO CONTEXTO BRASILEIRO}

O Brasil, onde este trabalho esteve centrado no último ano, abriu suas fronteiras ao neoliberalismo na década de 1990. Assim como o México e a Argentina, o Brasil é um país que não está no centro do sistema capitalista, mas que, por seu grande parque industrial e produtivo, tem importância estratégica em sua vinculação ao centro do capital mundial. Era a maior economia da América Latina e $14^{\text {a }}$ do mundo em 2005, segundo o Banco Mundial (2006), superando seu colonizador Portugal.

Como afirma Ricardo Antunes (2004), o projeto neoliberal desertificou política e socialmente o país desde que foi implantado pelo Governo do ex-presidente da República Fernando Collor de Mello, no início da década de 1990. Collor, como era conhecido, trouxe uma lógica privatista ao país, em vigência até hoje. Por ter sofrido impeachment em momento de união e organização de diversos setores da sociedade, Collor não conseguiu completar o desenvolvimento do projeto neoliberal no país. Sob o pretexto de combater a inflação, adotou medidas radicais como estas, em especial: promoveu a abertura do mercado brasileiro à exportação e importação e reduziu a intervenção estatal em quase todos os setores. Porém, estas medidas não contiveram a alta da inflação nem avançaram no processo de desenvolvimento do país. Collor era identificado pelos intelectuais, inclusive por Antunes (2004) e Sader (2003), como um político de direita, conservador e populista, claramente favorável à entrada do neoliberalismo no país, que ele identificava como porta para o avanço e desenvolvimento brasileiro.

A população barrou Collor pelo impeachment, mas não conseguiu barrar o projeto neoliberal. Assim, em seguida ao seu afastamento, sucedendo o vice-presidente de Collor, Itamar Franco, Fernando Henrique Cardoso (FHC) continuou o que Collor havia começado, desenvolvendo, como afirma Antunes (2004), o programa neoliberal.

FHC, identificado como intelectual de esquerda, denominava-se socialdemocrata, mas praticava o oposto do que pregava a social democracia ${ }^{11}$. Na gestão do país, adotou uma política macroeconômica excessivamente monetarista que teve na vulnerabilidade externa, no desemprego e no endividamento interno as maiores conseqüências. Com a defesa da moeda forte, o governo FHC trabalhou pela estabilidade da moeda - a altos custos sociais e dificilmente reversíveis - promovendo o

\footnotetext{
${ }^{11}$ A ideologia social-democrata prega uma gradual reforma do sistema capitalista a fim de torná-lo mais igualitário, geralmente tendo como meta o socialismo.
} 
desemprego recorde e o aumento do subemprego, ainda em acordo com o FMI, por meio de empréstimos de valores irrisórios a juros consideráveis sem contemplar a realidade social do Brasil.

De fato, o Governo Fernando Henrique Cardoso implantou um projeto econômico e político que facilitou, principalmente, o aprofundamento da doutrina neoliberal. Antunes (2004) afirma que, com um plano de estabilização monetária - o Plano Real - o governo conseguiu diminuir os índices inflacionários, mas recompôs o projeto burguês, desregulamentando a economia, efetivando a contra-reforma do Estado e privatizando parte substanciosa das atribuições públicas. Em acordo com o Fundo Monetário Internacional (FMI), FHC implantou o programa de ajuste fiscal, cumprindo as suas condições, como o pagamento da dívida externa.

Mas, na prática, o que significou um acordo com o FMI? O papel do FMI na atual conjuntura capitalista é promover ajustes estruturais, reformas na economia e combater o déficit público, adequando o neoliberalismo nos países em que implanta para alcançar uma organização econômica e social coerente entre as nações. O FMI encontrou condições políticas favoráveis à implantação de seu modelo hegemônico na década de 1990, em especial no Governo FHC. Por isso, o neoliberalismo triunfou com a "vitalidade impressionante", ressaltada por Anderson (1995).

FHC promoveu a hegemonia do capital financeiro, alcançou a estabilidade monetária e, para Sader (2003), "política e ideologicamente a operação foi um sucesso, com a reeleição de Cardoso, derrotando a esquerda..."; só que, social e economicamente, houve um desastre, identificado pela perda de poder aquisitivo, renda e direitos da população mais pobre e da classe média. O Estado se endividou ${ }^{12}$, foi pressionado pelas altas taxas de juros, pela entrada do capital especulativo e ainda privatizou grande parte das empresas públicas.

O capital financeiro dominou a conjuntura política de tal forma que, em troca de apoio do governo, até financiou campanhas eleitorais. Com FHC, o Brasil, como Estado, passou a viver em função do pagamento dos juros da dívida, conforme análises de Sader (2003) que denomina tal fato de "financeirização do Estado brasileiro". Mesmo provindo da oposição, inclusive intelectualmente, FHC deu esta enorme contribuição à direita neoliberal, opondo-se não só à esquerda, como aos sindicatos e aos movimentos sociais. Entre as transformações sociais e econômicas advindas da

\footnotetext{
${ }^{12}$ Sader (idem) calcula que o endividamento público tenha se multiplicado por cinco; passou de 54 bilhões, em 1994, para 550 bilhões, em 2000.
} 
transferência dos recursos para o setor financeiro, a mais brutal foi a expropriação dos direitos dos trabalhadores, em especial o direito ao trabalho formal, que abrange apenas pouco mais de $40 \%$ da população economicamente ativa - pois o trabalho informal atingia 58,1\% dos ocupados no Brasil a partir de dados do Censo Demográfico de 2000 (IBGE). Porém, mais que isso, o direito ao trabalho, como pré-requisito à renda, não foi defendido nem pelo governo nem pelos trabalhadores explorados.

Sader (2003) enfatiza a dimensão atingida pela apatia política devido à resignação das pessoas e do próprio governo em sua relação com os outros países e à desmoralização das soluções coletivas derivadas da organização consciente das massas com o objetivo de modificar a sua condição de vida. Condição esta que não poderia ser satisfatória, já que o Governo FHC acentuou a distância entre ricos e pobres, num modelo econômico excludente que não levava em conta os problemas estruturais do país, na visão de Sader (id), como a reforma agrária, a desigualdade social, a integração econômica nacional.

Outra dimensão do desastre do Governo FHC envolvendo as parcelas mais pobres esteve ancorada no programa Comunidade Solidária, impulsionado pela esposa de FHC, a primeira-dama Ruth Cardoso.

O Comunidade Solidária foi criado e institucionalizado entre as políticas sociais governamentais de combate à pobreza e à fome, com o intuito de desresponsabilizar o Estado de ações sociais e transferir esta responsabilidade para a sociedade civil, por meio de campanhas de incentivo ao voluntariado em nome da solidariedade e da cidadania. O governo dava o nome de parceria às ações desenvolvidas pela sociedade civil no campo da educação, saúde, alimentação, geração de renda, saneamento e habitação.

Entretanto, os dados mostram que a parceria entre sociedade civil e Estado não enfrentou com êxito a pobreza no Brasil. Segundo um estudo do Instituto Brasileiro de Geografia e Estatística (IBGE, PNAD - Pesquisa Nacional por Amostra de Domicílio, 1977), os miseráveis ${ }^{13}$ representavam, 29 anos atrás, uma parcela em torno de $17 \%$ da população. O índice divulgado em 2003 pelo mesmo instituto informa que a taxa de miséria estava em 14,5\%, em 1999 (IBGE, PNAD, 1999), quando o Governo FHC estava em vigor. No mesmo período, entre 1977 e 1999, o Produto Interno Bruto (PIB) cresceu 85\%, mas

${ }^{13} \mathrm{O}$ miserável é aquele que se encontra abaixo da linha de miséria (ou de indigência) correspondente a R\$ 115,00 mensais, que determina quem não consegue ganhar o bastante para garantir a mais básica das necessidades: a alimentação. A linha de indigência, endogenamente construída, refere-se somente à estrutura de custos de uma cesta alimentar, regionalmente definida, que contemple as necessidades de consumo calórico mínimo de um indivíduo. (Radar Social, 2005). 
esse crescimento representou pouco ou quase nada em termos de melhora da qualidade de vida da população miserável brasileira, na qual metade vive na Região Nordeste.

\subsection{A singularidade do Governo Lula}

A justificativa para a escolha do Governo Lula na análise deste trabalho é pautada no perfil populista ${ }^{14}$ deste governo, como afirma Boito $\mathrm{Jr}$ (2003), de um líder extremamente carismático que estabelece, de certa forma, um vínculo emocional com o povo, relembrando seu "passado de povo" (que significou um passado pessoal de pobreza e trabalho), para se eleger e ganhar legitimidade ao defender o povo. $\mathrm{O}$ populismo se relaciona à vitória nas urnas pela soma do envolvimento das classes pobres com a história de vida de Lula com sua identificação com a situação de pobreza do passado do candidato, além do chamado "fracasso" do governo anterior (Sader, 2003).

Lula, tendo reivindicado os direitos dos trabalhadores por toda sua trajetória de luta no movimento sindical, ficou marcado no ideário popular como um defensor de suas causas. Além de co-fundador do Partido dos Trabalhadores (PT), foi também fundador e presidente do Foro de São Paulo, que coordena as organizações de esquerda da América Latina. Foi candidato a presidente em 1989 (derrotado por Fernando Collor de Mello); em 1994 (derrotado por Fernando Henrique Cardoso) e em 1998 (novamente derrotado por Fernando Henrique Cardoso), tendo ganho as eleições de 2002 e reeleito em 2006.

A eleição de Lula gerou uma expectativa positiva na maioria da população por ele levantar bandeiras de esquerda desde sua militância no sindicalismo e suas primeiras candidaturas, defendendo teses de conteúdo socialista e antes identificado até com os ideais comunistas. Segundo Sader (2003), a maior preocupação dos organismos internacionais com a vitória de Lula foi saber se seu governo terminaria o trabalho começado por FHC e continuaria com as "reformas", mesmo tendo sido "eleito contra o modelo neoliberal". Porém, Lula, iniciando sua gestão em janeiro de 2003, buscou desde o início conseguir a aprovação e a confiança dos mercados, para ganhar

\footnotetext{
${ }^{14}$ Populista refere-se a uma série de movimentos políticos que se propõem a colocar, no centro de toda ação política, o povo, no sentido de massa. Há ainda o sentido ideológico de populismo como instrumento de manipulação do povo.
} 
credibilidade e apoio dos grupos hegemônicos que se estendeu aos organismos financeiros internacionais.

Sua gestão foi caracterizada por um governo de continuidade da estabilidade econômica do Governo anterior, e uma balança comercial crescentemente superavitária. Em seu governo, a dívida interna passou de 731 bilhões de reais (em 2002) para um trilhão de reais em fevereiro de 2006, último ano do primeiro mandato de Lula, apesar de não ter apresentado variação significativa em relação ao PIB nacional.

O governo gerou decepção na população, segundo Boito Jr (2003), porque a herança neoliberal de FHC foi mantida, principalmente no que diz respeito à economia: abertura comercial; desregulamentacão financeira; privatização; ajuste fiscal e pagamento da dívida; redução dos direitos trabalhistas; desregulamentação do mercado de trabalho. Além disso, Lula não repôs as perdas dos trabalhadores relativas aos governos anteriores. Seu governo não só deu continuidade às medidas econômicas neoliberais como tomou uma série de iniciativas nesta direção, como as reformas da previdência e tributária, que favoreceram o grande capital. Já o primeiro ano de governo causou grande estranhamento devido, em parte, à política externa adotada de aproximação com o governo norte-americano, inclusive aceitando a criação da agenda da ALCA (Área de Livre Comércio das Américas) e realizando parcerias com países como a China.

Mas por que será que o livre comércio que, segundo Bush e outros governos favoráveis à Alca levará ao “crescimento econômico e empreendedorismo, trazendo a prosperidade regional" ${ }^{\prime \prime}$, parece uma medida equivocada? François Chesnais, responde a esta pergunta com grande propriedade ao criticar o neoliberalismo em sua obra de maior repercussão: A Mundialização do Capital (1996). A sua explicação é a de que o livre comércio aumenta a liberdade de investimento das grandes corporações mundiais, dando-lhes, na prática, poder de criar e manipular um grande mercado de trabalho mundial, adentrando inclusive em campos que, em décadas atrás, constituíam conquistas dos trabalhadores e interferindo, pela privatização, em áreas como saúde, educação, previdência e infra-estrutura pública.

Os fatos relatados acima a respeito do governo Lula levam a pensar em uma mudança de orientação dos políticos, do governo e seus membros e do próprio Partido dos Trabalhadores, direcionando sua política em benefício da burguesia nacional e

\footnotetext{
${ }^{15}$ Trecho extraído da fala do presidente George Bush na Quarta Cúpula das Américas, em novembro de 2005. Sítio da internet: http://livrecomercio.embaixadaamericana.org.br/?action=artigo\&idartigo $=836$
} 
internacional. O Governo Lula manteve a orientação do projeto neoliberal, adotando uma política econômica que prejudicou o mundo produtivo, beneficiou os capitais financeiros, seguindo, como FHC, os ditames do FMI.

Ainda assim, este trabalho reconheceu a singularidade do Governo Lula, que não pode apenas encaixar-se na história do país por sua política “continuísta" em benefício dos mais ricos. Embora ele não tenha realizado rupturas com os governos neoliberais anteriores e muito menos com o capitalismo, ainda assim, a sua opção pelos mais pobres sempre esteve clara, mesmo sem retomar qualquer relação com o socialismo. Mesmo dando continuidade a muitas medidas econômicas do governo FHC, Lula avançou na proteção social como nenhum outro governo anterior. É o que será visto a seguir com base na análise de dois programas sociais deste governo. 


\section{A PROTEÇÃO SOCIAL NO GOVERNO LULA}

\subsection{Políticas sociais analisadas}

Um dos programas analisados por este TCC é o Bolsa-Família, que faz parte do Programa Fome Zero ${ }^{16}$. Criado em 2004, a partir da unificação dos programas Bolsa Escola, Bolsa Alimentação, Auxílio-Gás e Cartão Alimentação, consistia na concessão de benefícios mensais às famílias que recebiam até R\$100,00 "per capita" por mês, em contrapartida ao compromisso dessas famílias de garantir a freqüência escolar e cuidados com a saúde das crianças, adolescentes, gestantes e nutrizes. É importante mencionar que, desde abril de 2006, o Bolsa Família atende às famílias em situação de pobreza e extrema-pobreza, caracterizadas pela renda familiar mensal per capita de até $\mathrm{R} \$ 120,00$ e $\mathrm{R} \$ 60,00$, respectivamente, beneficiando também as famílias remanescentes dos quilombos. Mas, no início, a família devia se encaixar nos critérios estabelecidos no quadro abaixo.

\begin{tabular}{|c|c|c|}
\hline Renda Per Capita & Benefício Fixo & Renda Variável \\
\hline Até $\mathrm{R} \$ 50,00$ & $\mathrm{R} \$ 50,00$ & $\mathrm{R} \$ 15, \mathrm{R} \$ 30$ ou $\mathrm{R} \$ 45,00$, \\
& Não recebem & $\begin{array}{c}\text { conforme o número de crianças } \\
\text { e adolescentes de até } 15 \text { anos, } \\
\text { gestantes e nutrizes em cada }\end{array}$ \\
& & \begin{tabular}{c} 
família. \\
\hline
\end{tabular} \\
\hline
\end{tabular}

Radar Social 2006 - Principais Iniciativas do Governo Federal

Como o principal programa do Governo Lula na área social voltado para a família, o Bolsa Família destina-se a combater as distorções de renda existentes no país e é tido como o maior programa de transferência de renda da história do Brasil. Por meio do programa, o governo federal concede mensalmente benefícios em dinheiro às famílias que se encaixam no perfil focalizado pelo programa, que é coordenado pelo Ministério do Desenvolvimento Social e Combate à Fome.

Outro programa do governo federal analisado por esta monografia, também inserido no programa Fome Zero, em seu terceiro eixo intitulado "geração de renda", é

${ }^{16}$ O Fome Zero foi um chavão da campanha de Lula no período eleitoral e se transformou em estratégia de governo por ser a principal ação do Governo Lula na área social congregando as medidas estatais de combate à fome e à miséria. 
o Microcrédito Produtivo Orientado que, segundo o Radar Social 2006, destina-se a pequenos empreendedores, sejam pessoas físicas ou jurídicas, principalmente informais, que, devido à carência de opções de crédito e orientação, têm dificuldade em se estruturar e se formalizar. A metodologia empregada está baseada no relacionamento direto entre um agente de crédito e os empreendedores, que definem em conjunto as necessidades de crédito e de gestão do empreendimento.

No Brasil, a primeira experiência de microcrédito ocorreu em 1973, em Pernambuco, com o Projeto UNO. Entretanto, o microcrédito só ganhou força com o apoio do BNDES (Banco Nacional de Desenvolvimento Econômico e Social), a partir de 1996, com o Programa de Crédito Produtivo Popular, formando uma larga rede institucional no Brasil. Em seguida, outras iniciativas de bancos federais, estaduais, instituições financeiras e outras de apoio às micro e pequenas empresas favoreceram a expansão do microcrédito.

Em novembro de 2004, por meio da medida provisória $n^{\circ} 226$ de 29 de novembro de 2004, o Governo Lula lançou o Programa Nacional de Microcrédito Produtivo Orientado - PNMPO, no âmbito do Ministério do Trabalho e Emprego, para pequenos empresários com empréstimos de juros a 2\% ao mês. O PNMPO, depois instituído por meio da Lei 11.110, de 2005, que substituiu a medida provisória, considera "microcrédito produtivo orientado o crédito concedido para o atendimento das necessidades financeiras de pessoas físicas e jurídicas empreendedoras de atividades produtivas de pequeno porte ${ }^{17}$. Utiliza metodologia baseada no relacionamento direto com os empreendedores no local onde é executada a atividade econômica", entendendo como instituições de microcrédito produtivo orientado: as cooperativas singulares de crédito, as agências de fomento, as sociedades de crédito ao microempreendedor e as OSCIPs (Organizações da Sociedade Civil de Interesse Público).

O Microcrédito Produtivo Orientado é realizado pelas operadoras de microcrédito, através do agente de crédito. Esse agente tem a função de fazer o levantamento socioeconômico financeiro, ou seja, uma coleta de informações do seu negócio. Essas informações são encaminhadas ao comitê de crédito da operadora de microcrédito para avaliação. É destinado a empreendedores que precisam de pequenos valores financeiros e sem burocracia, mas com o objetivo de ampliar ou melhorar o seu

\footnotetext{
${ }^{17}$ Considera-se micro-empreendedores populares as pessoas físicas e jurídicas empreendedoras de atividades produtivas de pequeno porte, com renda bruta anual de até R\$ 60 mil.
} 
empreendimento, com limites de crédito de até $\mathrm{R} \$ 5.000,00$ por empreendedor, sendo permitido até $20 \%$ dos contratos com valores de até $\mathrm{R} \$ 10.000,00$.

As fontes dos recursos (620 milhões até os dias atuais) liberados pela União advinham dos depósitos à vista nos bancos públicos e privados (sendo $2 \%$ orientados para tal fim) e do Fundo de Amparo ao Trabalhador - FAT. O programa ainda hoje utiliza recursos do FAT - que destinou R \$ 30 milhões para 2006 - e de parcela dos $2 \%$ dos depósitos à vista dos bancos públicos e privados. Por meio do sistema de crédito produtivo orientado, as instituições de microcrédito emprestam o recurso ao microempreendedor e o acompanham durante o pagamento do empréstimo.

Para a implementação do Programa, foi criado o Comitê Interministerial do PNMPO, que é composto por representantes dos Ministérios do Trabalho e Emprego, da Fazenda e do Desenvolvimento Social e Combate à Fome. O Comitê Interministerial coordena e implementa o PNMPO, analisa suas prioridades, recebendo e elaborando proposições, além de acompanhar e avaliar sua execução.

Por seu potencial para gerar renda e emprego, o PNMPO foi analisado neste trabalho, da mesma forma que o Bolsa Família, como política de relevância da rede de proteção social do governo Lula.

\subsection{Análise dos programas selecionados}

Como a definição do grau de abrangência das políticas sociais está diretamente relacionada aos limites da intervenção do Estado, inclusive quanto às prioridades e aos recursos destinados aos programas sociais, a análise aqui realizada levou em consideração, principalmente, a amplitude da intervenção estatal. Procurou-se aquilatar o peso da intervenção do Estado na proteção social comprovado pela presença de políticas públicas na área social. Desta forma, para a análise, foram considerados três pontos principais, imprescindíveis à proteção social, relatados abaixo.

A proteção social esperada de um governo que adota o neoliberalismo como doutrina orientadora, ou qualquer governo que permita o funcionamento livre e desregulado do mercado com suas falhas ${ }^{18}$, é reduzida e insignificante, a menos que haja uma preocupação deste governo com a população mais vulnerável. Desta forma,

\footnotetext{
${ }^{18}$ As falhas aqui tratadas são denominadas externalidades negativas na Economia. A externalidade do mercado pode ser positiva ou negativa; no presente trabalho as falhas se restringem às negativas ou que trazem prejuízo.
} 
existem três pontos que devem ser considerados por um governo que decide combater as implicações da adoção do ideário neoliberal.

Primeiro, a proteção social deve ser composta por programas e políticas sociais que têm por objetivo a redução das desigualdades na distribuição de renda e dos níveis de pobreza dos cidadãos, isto é, que respondam às falhas do mercado.

O segundo ponto relevante é que a proteção social governamental deve se estruturar como uma rede que atenda a todos os eventos imprevistos, como desemprego, acidentes de trabalho, doenças, e às situações previsíveis como envelhecimento, maternidade, infância, comprometimentos físicos, acompanhadas de incapacidade para o trabalho e, conseqüentemente, incapacidade de geração de renda.

Ainda mais, em terceiro, é preciso que as políticas sociais possibilitem a todos os cidadãos a manutenção de um padrão de vida mínimo e digno, independente de situações previstas (mas sem hora para acontecer) e situações totalmente imprevisíveis antecipadamente. Aliada a essa condição, é preciso que a concepção da política social adotada seja considerada direito social e não favor ou benesse do Estado.

O Governo Lula elaborou e implementou diversos programas na área social visando, em tese, à redução das desigualdades sociais, o que, na prática, não representou uma redução tão enfática dessas desigualdades por não tocar no cerne da questão, que é a redistribuição da riqueza e da renda no país. Isso, segundo Márcio Pochman (2006), em curto prazo, é o mesmo que "secar gelo", pois apenas a transferência de renda não é a solução para a situação, por se tratar de política emergencial. Ainda assim, a medida tem seu valor a longo prazo.

A Fundação Getúlio Vargas (FGV) em parceria com pesquisadores do International Poverty Centre, da Organização das Nações Unidas (ONU), realizou a pesquisa chamada "Crescimento Pró-Pobre: O Paradoxo Brasileiro", divulgada em junho de 2006. A pesquisa concluiu que, em 2004, a renda média do brasileiro cresceu $3,6 \%$, enquanto a renda dos mais pobres chegou a crescer $14,1 \%$. Concluiu ainda que a distribuição de renda no governo Lula cresceu quatro vezes mais que nas duas gestões anteriores. De 2002 a 2006, a renda recebida pelos $50 \%$ mais pobres cresceu $0,53 \%$ ao ano. De 1993 a 2002, o crescimento foi de apenas 0,12\% anual, segundo dados anteriores da FGV. Isso mostra que houve sim um aumento na distribuição da renda entre os mais pobres, mas este crescimento não representa um avanço considerável para o país, já que a intervenção do governo não teve qualquer influência no montante maior da parcela da riqueza que fica com os mais ricos no país. 
O Instituto Brasileiro de Geografia e Estatística (IBGE) divulgou recentemente um estudo no qual quase 39 milhões de brasileiros foram beneficiados, em 2004, pelos programas sociais de transferência de renda do governo. A pesquisa confirma que estas ações, que atingiram $21,4 \%$ da população do país, estão de fato chegando as pessoas mais necessitadas. Segundo Eduardo Nunes, presidente do IBGE, "elas já beneficiaram 91\% dos domicílios com rendimento inferior a um salário mínimo". Em 2004, estes programas bateram o recorde histórico ao contemplar 50,3\% das consideradas "famílias miseráveis" ${ }^{19}$ pelo IBGE.

Por seu turno, o Índice de $\mathrm{Gini}^{20}$ melhorou um pouco, caindo de 0,583, em 2003, para 0,568, em 2005, segundo Relatório de Desenvolvimento Humano (RDH) de 2006 do Programa das Nações Unidas para o Desenvolvimento (PNUD), sugerindo que esta diminuição tenha sido causada pelos programas de transferência de renda governamentais. Este índice é o melhor dos últimos trinta anos, mas, trata-se de uma queda que representa muito pouco se levarmos em conta a grande barreira da desigualdade de renda entre os brasileiros. É por este motivo que, partindo de uma simulação, Paes de Barros $^{21}$ afirma que são necessários ainda mais 25 anos de programas de transferência de renda para que o Brasil chegue a um nível menos dramático de desigualdade social, próximo ao da Tunísia.

Analisar-se-á, separadamente, os programas sociais, abaixo.

\section{a) Bolsa Família}

O Bolsa Família procurou responder justamente ao primeiro ponto imprescindível à proteção social desejada, citado no início deste item ${ }^{22}$, que diz respeito à desigualdade de renda e redução da pobreza por meio da política social, em resposta às falhas do mercado. Desta forma, ainda que permita a hegemonia da sociedade de mercado, expressando suas externalidades inconvenientes na forma de não captação de todas as parcelas da população, mesmo que estabeleça um corte de renda para acessar o benefício, o governo, por meio do programa Bolsa-Família, foi capaz de dar resposta ao

\footnotetext{
${ }^{19}$ O IBGE considera "famílias miseráveis" aquelas que vivem com menos de um quarto do salário mínimo per capita ao mês.

${ }^{20} \mathrm{O}$ índice de Gini é uma medida da desigualdade de renda na qual o valor "0" corresponde à igualdade perfeita e o valor "1" à desigualdade absoluta.

${ }^{21}$ Palestra no Seminário Internacional "O Desafio da Redução da Desigualdade e da Pobreza" em 30/11/2006. Ricardo Paes de Barros é economista e pesquisador do Ipea.

${ }^{22}$ Item "Análise da proteção social"
} 
problema da pobreza e, em menor escala, da desigualdade, como previa o primeiro ponto desta discussão, em particular, pelo aumento do foco de atendimento.

A evolução das ações sociais do governo Lula, no que tange à cobertura dos programas, é mais significativa que à época de FHC. Com o Bolsa Família (ver Gráfico $\mathrm{n}^{\mathrm{o}}$ 1), o governo atingiu 3,6 milhões de famílias em 2003, 6,5 milhões em 2004, 8,7 milhões em 2005 e 11 milhões de famílias em 2006. Os recursos públicos investidos neste programa saltaram de R\$ 3,4 bilhões em 2003 para R \$ 8,3 bilhões em 2006 - na mais volumosa transferência de recursos da América Latina. Pesquisas encomendadas pelo Ministério do Desenvolvimento Social e Combate à Fome (MDS) revelam que as famílias beneficiárias do Bolsa Família estão comendo mais e melhor. Além disso, ao adotar condicionalidades, como a obrigatoriedade do acompanhamento dos centros de saúde para cuidados básicos de crianças, gestantes, nutrizes e da escola para as famílias que têm crianças em idade escolar, o Bolsa Família possibilita indicadores positivos de melhoria na saúde e na escolaridade, por exemplo. 


\section{Gráfico $\mathrm{n}^{\mathrm{o}} 1$}

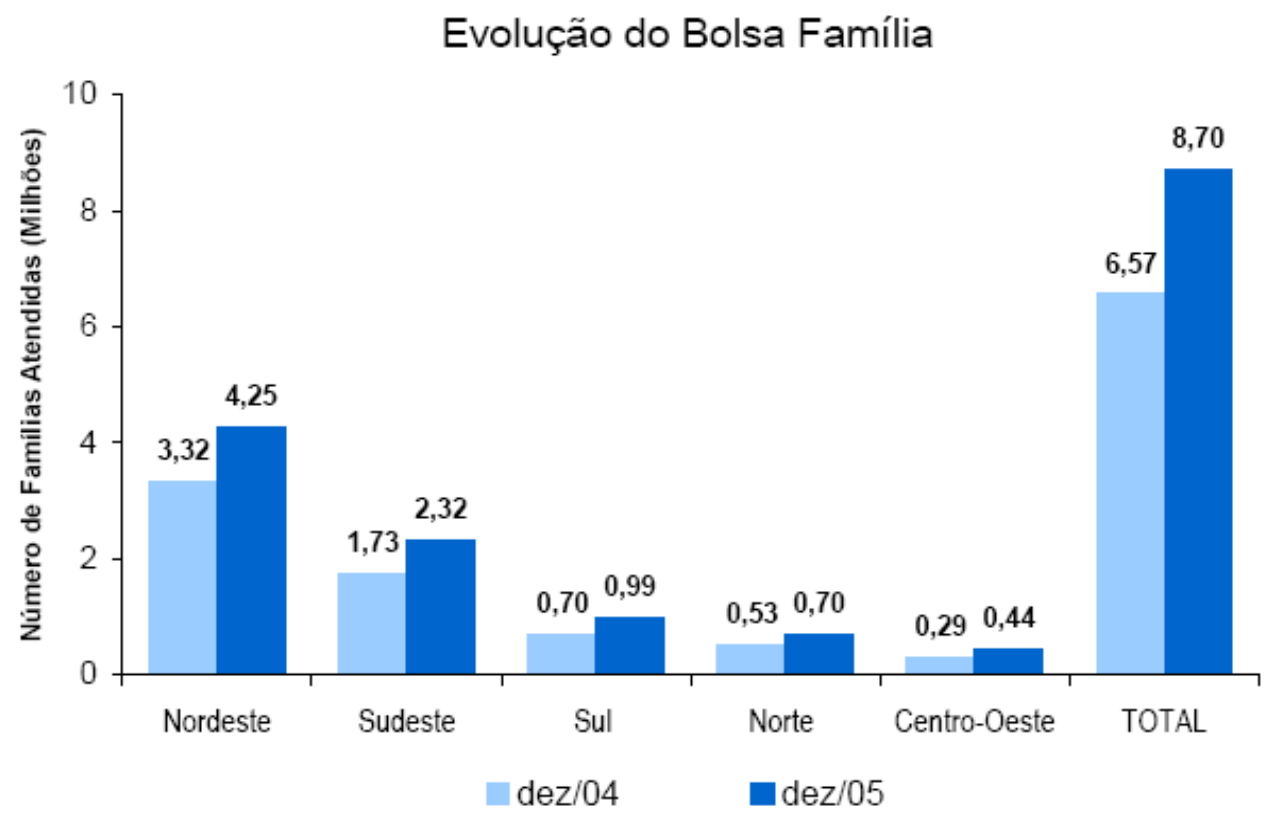

Fonte: Ministério do Desenvolvimento Social e Combate à Fome

O Bolsa Família considerou, em sua estratégia inicial de expansão, as desigualdades regionais, priorizando as regiões mais pobres. De cada 10 (dez) famílias atendidas pelo Programa, no final de 2005, quase 6 (seis) estavam nas regiões Norte e Nordeste, totalizando 4,94 milhões de famílias. Tendo em vista que até o final de 2006 a meta é universalizar a cobertura da população alvo, em 2005 alcançou um piso de cobertura de $70 \%$ em pouco mais de 4.000 municípios brasileiros.

Todavia, ainda que a cobertura dos programas sociais tenha aumentado, dados do PNAD (Pesquisa Nacional de Amostra por Domicílio) de 2004, divulgados pelo IBGE em 2006, indicam que 14 milhões de pessoas ainda estão, qualitativa e quantitativamente, em situação de insegurança alimentar no Brasil, o que significa 14 milhões de brasileiros que passam fome em algum período do mês. Esse é um dado que também dá margem a interpretações negativas sobre a insuficiência do valor do BolsaFamília para a satisfação das necessidades principais das famílias. 
O Bolsa Família tem um impacto maior que o salário-mínimo na redução da desigualdade, segundo o economista Paes de Barros na palestra já referida na nota de rodapé da página 37. O aumento do valor do salário mínimo real não supera a efetividade do Bolsa Família, se o valor for reajustado periodicamente.

Merece destaque, ainda, o avanço do programa no que se refere ao acompanhamento das suas condicionalidades, em particular, da educação. As crianças e adolescentes com idade de 6 a 15 anos, cujas famílias recebem o benefício, devem comparecer à escola, tendo freqüência mínima de $85 \%$. Mais de $97 \%$ das crianças/adolescentes que tiveram freqüência informada nos meses de maio a julho de 2005 garantiram a freqüência mínima requerida, segundo o Radar Social (2006).

A condicionalidade de freqüência aos centros de saúde como responsabilidade da família é relevante na garantia do direito social à saúde e ainda promove a ação do setor público de saúde na oferta de serviços para o acompanhamento do crescimento e desenvolvimento infantil, da assistência ao pré-natal e ao puerpério, da vacinação, bem como da Vigilância Alimentar e Nutricional de crianças menores de 7 anos.

Há ainda que considerar o potencial emancipatório do Bolsa Família pela possibilidade de escolhas que ele abre no rol de decisões da família, relacionado ao que Plant (2002) denomina "liberdade de exercitar habilidades e capacidades" (liberdade positiva). O Bolsa Família possibilita um certo poder de compra, que reverte na dinamização das economias locais dos municípios e, em menor escala, nas estaduais. Com a renda garantida entre os últimos cinco dias do mês vigente e os cinco primeiros do mês subseqüente, surge uma espécie de confiança por parte do comerciante que, assim como para aposentados, pensionistas e beneficiários do Benefício de Prestação Continuada (BPC), é aceito que se compre produtos alimentícios fiados.

O grande avanço do Bolsa Família está em possibilitar o acesso a alimentos e, portanto, combater à fome, efetivando um direito social básico. Porém, o grande debate que se vem fazendo no âmbito do governo e das pesquisas na área diz respeito à falha do programa quanto às chamadas "portas de saída"23, que ainda não representam uma cobertura adequada para dar resposta às necessidades das famílias.

Também não se pode perder de vista que o Bolsa Família se tornou um avanço na política de assistência social por ter desvinculado esse benefício da incapacidade para o trabalho, caráter inerente a outros programas voltados para crianças e adolescentes,

\footnotetext{
${ }^{23} \mathrm{O}$ termo "portas de saída" se refere às formas da família sair ou se desligar do programa e viver com recursos próprios, atendendo suas necessidades e seus direitos, sem precisar retornar posteriormente ao Bolsa Família ou demais programas de assistência social.
} 
idosos e pessoas com deficiência. Ainda assim, o Bolsa-Família indiretamente responde ao desemprego e às situações imprevistas (segundo ponto relevante da proteção social destacado na p.36), como as doenças, apesar de não combater de frente um problema tão grave como o desemprego, o que é um dos objetivos do Fome Zero. Também por este motivo se diz que o Bolsa Família precisa consolidar suas "portas de saída" para geração de renda e emprego às famílias, que, geralmente, estão fora do mercado de trabalho formal.

Por último, considerando o terceiro ponto (p. 36) que afirma que, independente das situações previsíveis e imprevisíveis, a rede de proteção social deve proporcionar a todos os cidadãos um padrão de vida mínimo e digno, analisando o Bolsa Família, não se pode acreditar que o programa atenda completamente a esse requisito, visto que o valor recebido pelas famílias é baixo, muito menor que um salário mínimo, que mal atende a um padrão mínimo e digno de vida no país.

Adotando a concepção de desenvolvimento humano do PNUD (Programa das Nações Unidas para o Desenvolvimento), que vai além do crescimento econômico pela expansão do direito de escolhas individuais, aliando desenvolvimento das pessoas, desenvolvimento para as pessoas e desenvolvimento pelas pessoas ${ }^{24}$, tem-se que o Bolsa Família pôde expandir os direitos de escolhas individuais e promover o desenvolvimento humano no Brasil. Entretanto, no que se refere a esta concepção de desenvolvimento humano, em particular do desenvolvimento para as pessoas, a apropriação dos resultados do mercado, a riqueza e a renda entre a população continua se dando de forma muito desigual, o que ainda é um desafio não só para o Bolsa Família, como para todas as ações do governo.

\section{b) Programa Nacional de Microcrédito Produtivo Orientado - PNMPO}

Em primeiro lugar, é inevitável observarmos o fato de que as experiências de microcrédito são destacadas em todo o mundo por serem destinadas às pessoas mais pobres, com procedimentos relativamente simples de avaliação e aprovação de crédito, com mais rapidez, além de estimularem as atividades econômicas locais. É evidente que contando com um crédito, por reduzido que seja, o pequeno empresário dispõe de um recurso que lhe abre um leque de possibilidades.

\footnotetext{
${ }^{24}$ A concepção de desenvolvimento humano do PNUD, obtido através do Relatório de Desenvolvimento Humano (2003) compreende o desenvolvimento das pessoas, pelo aumento de suas potencialidades, oportunidades, capacidades e direitos de escolha; o desenvolvimento para as pessoas pela apropriação eqüitativa dos resultados por todos; e o desenvolvimento pelas pessoas, pela elevação do poder dos indivíduos, beneficiários do processo de desenvolvimento.
} 
O Governo Lula apresentou avanços concretos, uma vez que 1,4 bilhões de reais foram destinados ao crédito popular e ao microcrédito e, segundo dados do Ministério da Fazenda ${ }^{25}$, o número de contratos realizados e de recursos destinados para o microcrédito, entre os anos 2003 e 2005, quando comparados ao governo anterior de 1997 a 2002, aumentou em mais de 30\%.

Atualmente, o número de clientes ativos no Brasil chega a 324 mil e, segundo o coordenador do PNMPO, Almir Pereira, há condições técnicas e financeiras para pelo menos duplicar este número. Para atingir a meta, o Ministério afirma que o governo, os bancos e a sociedade civil teriam que investir em metodologia, orientação, gestão e funding (consolidação financeira das dívidas de curto prazo num prazo adequado ao fortalecimento do investimento e sua amortização). $O$ problema é que a responsabilidade compartilhada compromete o investimento neste tipo de serviço, já que poucos decidem assumir a tarefa de instrumentalizar o micro empreendedor que obtém o crédito. A própria lei é falha neste ponto, já que trata do assunto apenas em um artigo:

“Art. 5o O Ministério do Trabalho e Emprego poderá (grifo meu) celebrar convênios, acordos, ajustes e outros instrumentos que objetivem a cooperação técnicocientífica com órgãos do setor público e entidades privadas sem fins lucrativos, no âmbito do PNMPO.” (Brasil, lei 11.110/2005)

Note que o verbo empregado no texto da lei, "poderá", não levanta qualquer obrigação por parte do governo. A lei não define a responsabilidade dos agentes ${ }^{26}$ que atuam no programa quanto à orientação e apoio ao micro empresário no uso do recurso obtido. O pequeno empreendedor fica totalmente responsável pelo planejamento dos gastos que fará com o recurso, exceto quando, em experiências dispersas, o próprio cliente procura uma instituição de apoio ou quando a sociedade civil se incumbe desta tarefa, como no caso dos Sebraes. Porém, as experiências das organizações da sociedade civil são isoladas, impossibilitadas de atingir toda a demanda.

Conforme dados do próprio Ministério, o programa brasileiro conta, atualmente, com 324 mil clientes ativos, que totalizam empréstimos da ordem de R\$ 300 milhões. Os bancos públicos e privados repassam os recursos para as instituições de microcrédito habilitadas pelo PNMPO, com mais de 300 pontos, que atendem a 4.321

\footnotetext{
${ }^{25}$ disponível em 17/11/2006 no sítio http://www.fazenda.gov.br/portugues/documentos/2005/Microcredito_Microfinan\%C3\%A7as_do_Gov_ Lula_01-09-05.ppt\#355,21,Microcrédito Produtivo orientado

${ }^{26}$ Agentes são aqui entendidos como os participantes do processo: governo, bancos e sociedade civil.
} 
municípios. Entretanto, o programa ainda não atende a demanda de microcrédito para as micro e pequenas empresas, com um baixo índice de cobertura, como afirma Bárbara Costa em estudo recente (2006).

A mesma autora ainda destaca que na América Latina, segundo estudos do BID sobre as organizações que operam microcrédito, há presença marcante de instituições de pequeno porte de sustentabilidade financeira duvidosa, falta de informações confiáveis, altos custos operacionais e baixa produtividade dos agentes de crédito. Além disso, no caso do Brasil, o governo é ineficiente quando não proporciona outros serviços importantes que acompanham o crédito, como nos exemplos de Costa (2006): conhecimento sobre métodos e tecnologias de melhoria da produtividade, informações sobre o mercado e gestão administrativa, oferta de sistemas de saúde e segurança social.

A capacidade limitada do microcrédito também pode estar relacionada ao paradigma liberal adotado em muitas instituições de microcrédito, que conforme Costa (idem), atuam baseadas na concepção de que o crédito é utilizado com eficácia se disponibilizado aos pobres que o merecem, contemplando apenas os que têm habilidades e capacidades empresariais em um mercado acessível para os seus produtos. Contrário a esta concepção, o paradigma emancipatório considera o microcrédito capaz de constituir redes anticapitalistas se as instituições de microcrédito se integrarem a projetos de desenvolvimento econômico e social com esse objetivo. Desta forma, percebe-se, como conclui a autora, que o microcrédito praticado em muitas instituições brasileiras ainda é um crédito pequeno.

O governo, através do programa de microcrédito, consegue efeitos positivos, já que é capaz de: criar capacidade de trabalho autônomo para os pobres, além de incentivar, a longo prazo, o investimento nas famílias, que, com o tempo, promovem melhorias em suas condições de habitação, alimentação, saúde, educação das crianças; produzir investimento na comunidade; dinamizar a economia local e fortalecer a solidariedade coletiva. $\mathrm{O}$ microcrédito pode ser um tipo de empoderamento, segundo Costa (2006), se os principais interessados participam do processo e se o microcrédito é combinado ao investimento em outros serviços, como o conhecimento.

A principal limitação dos programas de microcrédito é a concorrência desleal enfrentada pelos pequenos produtores devido ao poder e à hegemonia de grandes empresas internacionais, mundializadas, experientes, com alta tecnologia e conhecimentos avançados na gestão de seus negócios. Por mais que os 
microempreendedores consigam manter-se no mercado por mais tempo com o impulso do programa de microcrédito, dificilmente expandirão seus negócios a ponto de atingir padrões internacionais de produção e distribuição de seus produtos, para concorrer em pé de igualdade com os grandes empresários.

\subsection{Desafios e Limitações}

O Governo Lula, assim como os governos que assumiram o país anteriormente, se depararam com desafios e limitações presentes na estrutura econômico-social e na história do Brasil há séculos. A situação de desigualdade, pobreza, fome e miséria, marcante na história brasileira, permanece na contemporaneidade, ultrapassando o século passado e acompanhando o início do novo milênio. Somam-se a este, outros problemas, como a precariedade do controle democrático sobre as políticas sociais.

É, de fato, injusto haver miséria, como afirma Mendonça (2003), se pensarmos em um país de proporções continentais, que, nos últimos 20 anos principalmente, superou muitas questões de ordem econômica, estando entre as quinze maiores economias do planeta. O Brasil se tornou o país que, por um lado, tem quase metade dos internautas da América Latina e comporta na cidade de São Paulo a segunda maior frota de helicópteros do mundo; mas, por outro, não garante condições para o desenvolvimento físico, intelectual e social de parcela considerável da população. É incrível como o Brasil acompanhou a evolução tecnológica dos países ditos desenvolvidos, construindo serviços e produtos de referência internacional, como a cardiologia na área da medicina curativa e pesquisas científicas. Entretanto, ainda mais incrível é o fato de estar entre os mais desiguais do planeta mesmo com tanta riqueza.

Uma rede de proteção social eficiente exige uma ação estatal de longo prazo, tendo continuidade em todos os governos e primando pela redistribuição da renda no país. A proteção social, em particular dos mais pobres, é uma escolha que pode vir a desfavorecer as classes dominantes, mas que, como afirma Chesnais (2004) depende de uma "ruptura radical" do governo com o sistema econômico atual.

Um conjunto de ações governamentais é imprescindível ao aprimoramento do modelo de proteção social visando à melhoria do bem-estar social da população. Uma alternativa conveniente, como afirma Singer (1997), seria conjugar: 1) redistribuição de 
renda, 2) controle da conjuntura e 3) condução do desenvolvimento das forças produtivas, o que na minha visão pode combinar as medidas de: 1) expansão de emprego e renda; 2) políticas sociais universais proporcionando igualdade de oportunidades entre todos; 3 ) políticas sociais focalizadas voltadas para as classes mais vulneráveis.

No Brasil, a Seguridade Social, composta pelas políticas de saúde, assistência social e previdência social, presente na legislação do país desde o texto constitucional ${ }^{27}$ vigente, passando por diversas regulamentações posteriores no início da década de 1990, só teve uma entre suas políticas que fosse universal: a saúde. Mas, ainda hoje, há quem discuta o acesso universal aos serviços de saúde na realidade de desigualdade de acesso aos direitos no Brasil.

A previdência social, de caráter contributivo, só atende aos trabalhadores formais ou aos que tenham condições de contribuir freqüentemente; por isso, ainda que atenda a uma parcela considerável de trabalhadores e aposentados da população brasileira, não pode ser considerada universal por não alcançar o trabalho informal em sua intensidade (e precariedade) atual. A previdência, segundo Boschetti (2003), reforça o seguro social de perspectiva restrita condicionado ao trabalho pelos contribuintes.

A assistência social, atuando de forma focalizada junto aos mais vulneráveis, atende a idosos e pessoas com deficiência extremamente pobres por meio do $\mathrm{BPC}^{28}$, constitui um outro expressivo programa de transferência de renda que, junto com o Bolsa Família, passou, no governo Lula, a atender às famílias mais pobres. Todavia, a assistência social tem sido marcada por uma história de financiamento engessado e segmentado, segundo Boschetti (2003). Mesmo com a construção do SUAS (Sistema Único de Assistência Social) $)^{29}$ que impulsionou mudanças e inúmeras reflexões por gestores e pesquisadores da área, a política de assistência ainda não cobre toda a parcela mais vulnerável da pobreza brasileira, por ser extremamente seletiva, limitada e focalizada nos mais pobres.

Não se pode esquecer das dificuldades de financiamento que as políticas sociais vem enfrentando desde que o neoliberalismo adentrou no país, persistindo esta

\footnotetext{
${ }^{27}$ Brasil. Constituição Federal de 1988

${ }^{28}$ BPC é o Benefício de Prestação Continuada no valor de um salário mínimo mensal aos idosos e pessoas com deficiência com renda mensal de até um quarto do salário mínimo per capita. Dados obtidos pelo sítio do MDS.

${ }^{29}$ O SUAS foi aprovado na Norma Operacional Básica da Assistência Social - NOB/SUAS, pela resolução ${ }^{\circ}$ 130, de julho de 2005, do Conselho Nacional de Assistência Social, estabelecendo o funcionamento do SUAS como sistema público não-contributivo, descentralizado e participativo..
} 
dificuldade na atual conjuntura. Sabe-se, por meio de diversos estudos, como o de Ivanete Boschetti (2003), que as prioridades de alocação de recursos respondem a interesses do grande capital como o pagamento da dívida financeira, fazendo com que os recursos sejam retirados das contribuições sociais criadas para aumentar os gastos redistributivos da Seguridade Social, que sempre teve um orçamento próprio previsto em lei. Contudo, na prática, o pagamento dos juros das dívidas ganha o caráter de inadiável, enquanto as políticas de proteção social, mesmo as da Seguridade, pautadas na legalidade, ficam à míngua. 


\section{CONCLUSÕES}

Em grande parte, a hipótese desse trabalho foi confirmada, já que realmente as medidas do governo Lula favoreceram o mercado muito mais que à população brasileira. A exploração da força de trabalho pela submissão a ocupações residuais pela maioria, que Pochman afirma estarem vinculadas à prestação de serviços aos ricos (empregados domésticos, jardineiros, motoristas, seguranças, trabalhadores da construção civil e decoração, vendedores de artigos de luxo, passeadores de animais, dentre outras ocupações), é um fato que comprova como são poucos os que se apropriam da riqueza produzida socialmente e se beneficiam do neoliberalismo.

Por meio deste trabalho ainda foi possível conhecer as implicações do neoliberalismo na política social brasileira, objetivo geral do estudo realizado. Também, como resultados esperados, foi possível reconhecer os efeitos negativos das políticas sociais neoliberais na condição de vida da população; analisar, embora que minimamente pela extensão deste trabalho, o modelo de proteção social implementado pelo Governo Lula; e desmistificar a idéia de que o Governo Lula, por ser vinculado a um partido de esquerda, tenha rompido radicalmente com a lógica de intervenção dos dois governos anteriores, de direita e com fundamento neoliberal, apesar de representar um avanço na proteção social brasileira.

Pela análise dos programas de governo, ficou evidente que a proteção social avançou, especialmente, pelo impacto que incidiu sobre a renda das famílias mais pobres, um dos fatores positivos na redução da pobreza. A política social, nem sempre direcionada para garantir os direitos de cidadania, como deveria, avançou por uma perspectiva. Contudo, por outro ângulo e considerando o aprofundamento do ideário neoliberal no país, percebeu-se certa estagnação nestas mesmas políticas.

Com o Bolsa Família, em particular, foi possível evidenciar uma cobertura ampla que bateu um recorde histórico de resposta à pobreza. Incidiram ainda outros fatores, além da ampliação da cobertura e do atendimento, considerados positivos neste trabalho. Por seu potencial emancipatório, seus indicadores positivos nas áreas de saúde e educação, por seu impacto maior na redução da desigualdade social, pela dinamização das economias locais, com o aumento do poder de compra das famílias, por considerar as desigualdades regionais, o Bolsa Família se apresentou como avanço na área social. Porém, ainda assim, é mister que atinja os milhões de brasileiros ainda em situação de insegurança alimentar e que apresente melhorias urgentemente no que tange às suas 
portas de saída, criando alternativas reais para as famílias saírem da condição em que se encontram.

Com intensidade de cobertura aquém do Bolsa Família, o microcrédito, outro programa analisado neste trabalho, se mostrou insuficiente para a demanda existente. Longe de proporcionar o atendimento necessário aos pequenos produtores beneficiados, o PNMPO não ofereceu, no primeiro mandato de Lula, a orientação e o apoio técnico que tornasse menos desigual a competição com as empresas maiores, permitindo ainda falhas gerenciais em suas operadoras, inclusive na adoção de uma concepção liberal de crédito, que só comportava os "merecedores" como beneficiários genuínos do programa. Todavia, este trabalho reconheceu a direção positiva do programa que incentivou o trabalho independente, estimulou as atividades econômicas locais, apresentando o microcrédito como uma forma de investimento a longo prazo nas condições de vida das famílias.

Dotar o país de um sistema eficiente de proteção social é tarefa difícil. Ultrapassa as responsabilidades do governo federal e carece de um período maior para se efetivar. Exige a ação dos três poderes da República, dos demais entes federados, a participação ativa e responsável da sociedade civil no controle democrático e a ação do setor privado. Não é bem-vindo o setor privado se utiliza o termo "social" como estratégia para melhorar sua imagem e obter incentivos fiscais, como acontece com sua falsa ética chamada "responsabilidade social", mas desde que respondendo a uma tendência ou projeto estatal de construção de uma sociedade mais justa e protegida socialmente. Com certeza, não é tarefa de um Governo, mas de todos os governos e com o apoio da população.

Mesmo não rompendo radicalmente com o neoliberalismo, o Governo Lula tem uma função social que nenhum outro governo teve. A proteção social do Governo Lula não efetiva todos os direitos sociais. Por maior cobertura que possam ter, nenhum dos dois programas analisados, nem o Bolsa Família nem o PNMPO podem garantir a justiça social ou transformar a proteção social brasileira se não ocorrer uma atitude de avanço maior na direção da redistribuição de renda, que bateria de frente com a doutrina neoliberal adotada, o que, em última instância, requisitaria uma mudança na postura política do Governo Lula.

Ainda assim, o governo atual superou o anterior, FHC, ao demonstrar preocupação e dar maior ênfase à área social, em particular, em seus programas de transferência de renda que, embora necessitem ser aperfeiçoados e consolidados, 
provocaram mudanças nas condições de vida de muitas famílias brasileiras. Para que o Brasil construa uma rede de proteção social ampla e eficaz e avance na direção da justiça social, medidas importantes necessitam ser tomadas pelo Governo Lula, inclusive aquelas que contrariam o ideário neoliberal, modelo que desprestigia a atuação do Estado na proteção social.

Qualquer reflexão atual do neoliberalismo, assim como do Governo Lula e de suas implicações, é incompleta e provisória. Este é um movimento ainda inacabado. Por enquanto, contudo, é possível tomar uma posição acerca da atuação do neoliberalismo durante mais de duas décadas nos países mais ricos do mundo, a única área onde seus resultados parecem consolidados e maduros. Como diz Anderson (1995) economicamente, o neoliberalismo fracassou, não conseguindo nenhuma revitalização do capitalismo avançado. Socialmente, o neoliberalismo conseguiu muitos dos seus objetivos, criando sociedades marcadamente mais desiguais, embora não tão livres da intervenção estatal como queria. Mas, política e ideologicamente, o neoliberalismo avançou como nem seus fundadores imaginaram, disseminando a idéia de que não há saída para suas normas, de forma que todos só podem acomodar-se. (Anderson, 1995, p. 22)

A hegemonia neoliberal alcança uma abrangência cada vez maior, ainda que muitas pessoas venham pensando novas alternativas de resistência. A tarefa destes opositores do neoliberalismo é a de oferecer outros modelos a partir de receitas novas, segundo Anderson (1995). Não se sabe quando a ruptura com o modelo neoliberal ganhará força (nem que curso seguirá o próximo mandato de Lula).

"Historicamente, o momento de virada de uma onda é uma surpresa"- Perry Anderson $(1995-$ p.23) 


\section{REFERÊNCIAS BIBLIOGRÁFICAS}

ANDERSON, Perry. Balanço do Neoliberalismo. In: SADER \& GENTILLI. Pós-neoliberalismo: as políticas sociais e o Estado democrático, Rio de Janeiro: Paz e Terra, 1995.

ANTUNES, Ricardo. A desertificação neoliberal no Brasil (Collor, FHC e Lula).Campinas: Autores Associados, 2004.

BOITO Jr, Armando. A hegemonia neoliberal no Governo Lula. Revista Crítica Marxista ${ }^{\circ}$ 17. São Paulo: Editora Revan, 2003.

BONAVIDES, Paulo. Curso de direito constitucional 7 ed. São Paulo: Malheiros, 1997.

BOSCHETTI, Ivanete. Assistência Social no Brasil: um direito entre originalidade e conservadorismo. 2 ed. Brasília: Ivanete Boschetti, 2003.

BRASIL, Constituição Federal de 1988.

BRASIL. Radar Social 2006: Principais Iniciativas do Governo Federal. Ministério do Planejamento, Orçamento e Gestão. Brasília: MP, 2006.

CHESNAIS, François. A Mundialização do Capital. Tradução de Silvana Finzi Foá. São Paulo: Xamã Editora, 1996.

"Ruptura radical" é a saída para o Brasil, defende professor francês.

Entrevista à Folha de S. Paulo, por Cíntia Cardoso, em 31/05/2004. Disponível em www.folhaonline.com.br

COSTA, Bárbara. Microcrédito ou Crédito Pequeno? A experiência dos financiados do Programa Providência do Recanto das Emas e Riacho Fundo II, do Distrito Federal. Tese de doutorado apresentada ao Departamento de Sociologia. Brasília: Universidade de Brasília, 2006.

DUARTE, Júlio César Pacheco. Estado, políticas sociais e cidadania no ideário neoliberal - uma interlocução com Roberto Campos. Dissertação de mestrado. Brasília: UnB, 1997.

ESPADA, João Carlos. Direitos sociais de cidadania. Uma crítica a F. von Hayek e Raymond Plant. Imprensa Nacional, Casa da Moeda. Coleção Análise Social 1997.

GARZA TOLEDO, Henrique. Estado e Políticas Sociais no Neoliberalismo. São Paulo: Cortez, 1995. 
HAYEK, Friedrich August von. O Caminho da Servidão; tradução de Leonel Vallandro. 2a ed. São Paulo, Globo, 1977.

LUZ, Paulo Martorelli. A ideologia da reforma gerencial do aparelho de Estado brasileiro no período 1995 - 1998: uma perspectiva crítica. Dissertação de mestrado. Brasília: UnB, 2004.

MENDONÇA, Ricardo. O paradoxo da miséria. Fundación para un nuevo periodismo iberoamericano. FNPI, 2003. Disponível em 18/11/2006 Internet: http://www.fnpi.org/premio/2003/finalistas/pdf/2003CSC1270p.pdf

MESZAROS, Istvan. Para além do capital: rumo a uma teoria da transição. São Paulo: Boitempo, 2002.

MINAYO, Maria Cecília de Souza. O Desafio do Conhecimento: pesquisa qualitativa em saúde. 7. ed. São Paulo: Hucitec, Rio de Janeiro: Abrasco, 2000.

MORAES, Reginaldo. Neoliberalismo: de onde vem, para onde vai? São Paulo: SENAC, 2001.

PEREIRA, Potyara Amazoneida Pereira. Necessidades humanas: subsídios à crítica dos mínimos sociais. São Paulo: Cortez, 2002.

Alternativas Socialistas às Politicas Sociais Neoliberais. In: SER Social n ${ }^{\circ} 13$. Programa de Pós-graduação em Política Social. Departamento de Serviço Social da Universidade de Brasília. Julho a Dezembro de 2003. A Política Social no contexto da política pública, da cidadania e da relação entre Estado e Sociedade. Curso de Especialização à Distância: Política Social e Desenvolvimento Urbano. Brasília: 2005.(digitado)

Por uma nova concepção de seguridade social. SER Social 7 Seguridade Social. Revista do Programa de Pós-graduação em Política Social. Brasília: UnB, julho-dezembro de 2000.

PISÓN, José Martinez de. Políticas de bienestar: un estudio sobre los derechos sociales Madrid: Tecnos, 1998.

PLANT, Raymond. Can there be a right to a basic income? 9th International Congress Geneva, $2002 . \quad$ Deptember, em: $<$ http://www.etes.ucl.ac.be/BIEN/Files/Papers/2002Plant.pdf $>$

PNUD / IPEA / FJP. Atlas de Desenvolvimento Humano no Brasil. Software 1.0.0 : ESM consultoria, 2003. 
POCHMANN, Marcio. Economia Solidária no Brasil: limites e possibilidades. In: Nota técnica - mercado de trabalho. Brasília: Ipea, 2004. Redução, em parte. Entrevista. Revista do Terceiro Setor. Junho de 2006. Internet.

Disponível dia $16 / 10 / 2006$ em: http://arruda.rits.org.br/notitia1/servlet/newstorm.notitia.apresentacao.ServletDeSecao?c odigoDaSecao $=10 \&$ dataDoJornal $=1151692952000$

POLANYI, Karl. A grande transformação. As origens da nossa época. Rio de Janeiro: Campus, 1980.

SADER, Emir. A vingança da história. São Paulo: Boitempo Editorial, 2003.

SCHAFF, Adam. O Futuro do Trabalho e do Socialismo. Revista O Socialismo do Futuro n.06 1993.

SIMMEL, Georg. "O indivíduo e a liberdade”. In: Jessé Souza e B. Oëlze, orgs. Simmel e a Modernidade. Brasília: Editora UNB, 1998.

SINGER, Paul. O papel do Estado e as políticas neoliberais. Metropolização e Políticas Neoliberais. São Paulo: EDUC, 1997.

SPOSATI, Aldaíza. A Constituição de 1988 e o percurso das políticas sociais públicas o Brasil. In: LOPES, José Rogério (Org.). O processo de democratização na sociedade brasileira: 20 anos de luta pela cidadania. São Paulo: SESC/NEPPS -UNITAU, 1999.

Regulação social tardia: característica das políticas sociais latinoamericanas na passagem entre o segundo e terceiro milênio. Trabalho apresentado no VII Congreso Internacional del CLAD sobre la Reforma del Estado y de la Administración Pública, Lisboa, Portugal, 8-11 Oct. 2002.

TEIXEIRA, Francisco J. S. e OLIVEIRA, Manfredo Araújo de. O neoliberalismo em debate. In: Neoliberalismo e Reestruturação Produtiva: as novas determinações do mundo do trabalho. São Paulo: Cortez, 1996, cap. V p. 195-252.

VIEIRA, Liszt. Cidadania e Globalização. Rio de Janeiro: Record, 1997. 